\section{SAAAA \\ JOURNAL}

Journal of Archaeology and Fine Arts in Southeast

Asia

Published by the SEAMEO Regional Centre for Archaeology and Fine Arts (SPAFA)

\title{
Kalapa - Jacatra -Batavia - Jakarta: An old city that never gets old
}

Annissa Gultom

Museologist/Archaeologist

www.tribuanakomunika.com

Jakarta, Indonesia

annissa.gultom@gmail.com

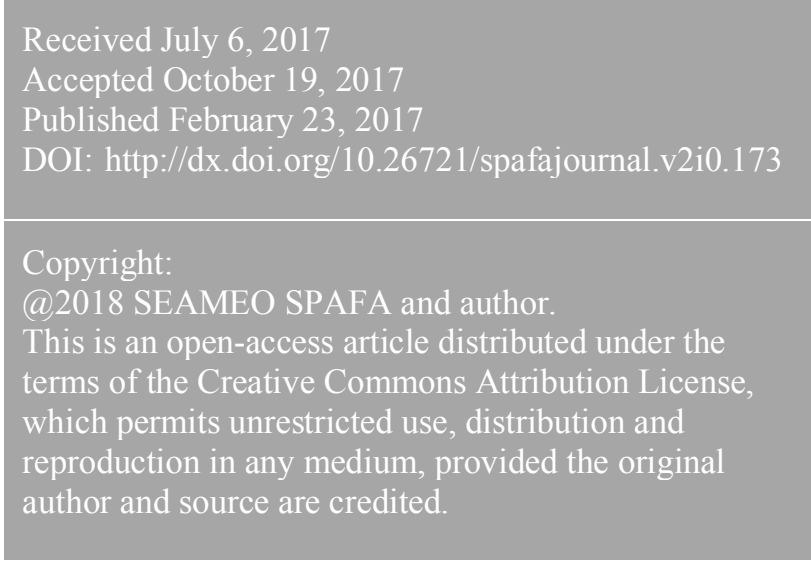

\begin{abstract}
The archaeology of Jakarta is a multi-layered artefact compounded with thin period separations. In the geographical sphere of the "greater Jakarta area", its roots start from the Neolithic with the discovery of Buni tradition pottery. The Buni area stretched along the north coast of west Java towards the interior to the south. This geographical sphere then became the oldest kingdom in the archipelago, Tarumanagara, an Indian-influenced Hindu Kingdom. A series of different ancient kingdoms ruled until the arrival of the Europeans. First, the Portuguese signed a treaty with Sunda (a Hindu Kingdom and ruler of the port of Kalapa) to defend their territory from Cirebon (an Islamic Kingdom in the eastern part of west java). Kalapa became a prized area that was fought over until the Dutch East India Company (Vereenigde Oostindische Compagnie, or VOC), led by J. P. Coen, burnt it down and built Batavia. Kalapa, as one of the few main ports of Sunda, historically welcomed people (with or without their will) from different areas. The influx of multicultural influence through this port continued when Batavia became the capital of the VOC, and then for the Netherlands Indies. The area grew into what is now known as the greater area of Jakarta. Although this greater area is now delineated into three different provinces, the cultural span of the area is still the same. A version of this paper was delivered as part of SEAMEO SPAFA's Capital's Archaeology Lecture
\end{abstract}


Series on 23 May 2017 at the Siam Society, Bangkok. This paper has been peerreviewed. The lecture can be viewed here: http://bit.ly/2imigGG

Keywords: Kalapa, Nusa Kalapa, Sunda Kalapa, Jakarta, Jayakarta, Old City, Archaeology, Capital, Port City, Indies, Sunda Kelapa, Nusantara, Indonesia

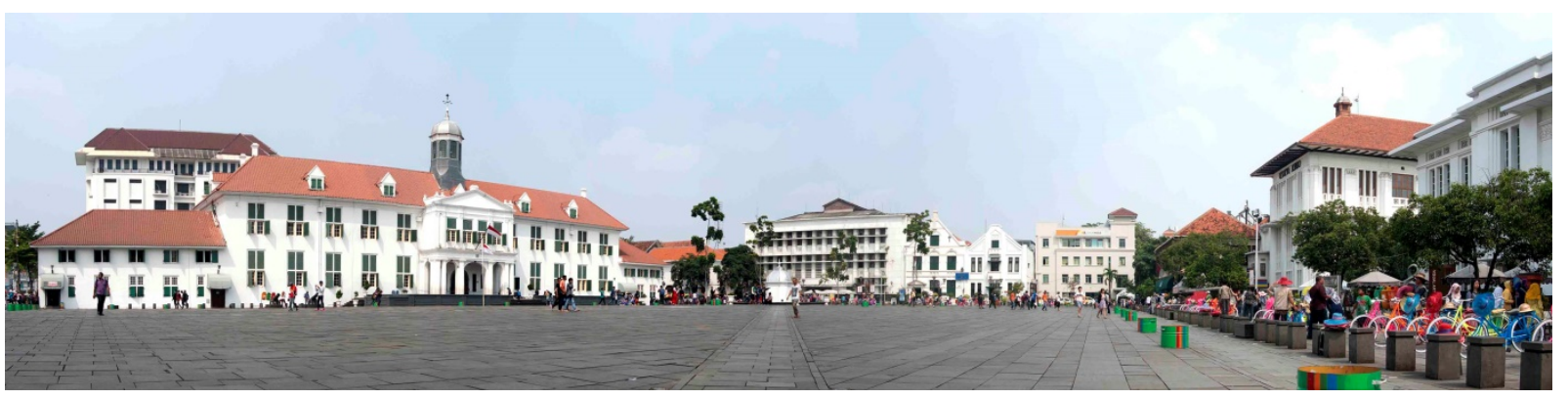

Fig. 1 Jakarta History Museum and Fatahillah Square. Source: Setio Martinus 2016.

\section{Introduction}

Jakarta is a complicated multi-layered cake of human civilization starting from the earliest layer of fine-polished stone tools and pottery from 3,500 BCE into the metropolis we know today. The city was an-ever growing place from at least the past two millennia and the confrontation between surviving heritage and city development is an on-going fight. Jakarta's cultural stratigraphy is dense with layers of superimposing civilizations that piled over each other; this is particularly shown by how remains of the old kingdom of Tarumanagara $\left(5^{\text {th }}\right.$ century $\left.\mathrm{CE}\right)$ is found in the vicinity right over the agricultural and bronze-iron periods of prehistory that lasted from $3500 \mathrm{BC}$ until the early centuries. Archaeological remains found in the greater Jakarta area show an overlap of continuous occupation from prehistory up to the colonial period that ended in the 1940s. The Tugu Inscription of the Tarumanagara kingdom, one of the oldest Javanese inscriptions from $5^{\text {th }}$ century CE, was found in the Tugu area near where the Tanjung Priok International Port is now located, which is also close by with the Sunda Kalapa port, the oldest port in Jakarta. The Tugu inscription is distinct as it was inscribed on a prepared egg-shaped andesite, unlike other inscriptions of the period. The inscription commemorates a canal made by the king's father to overcome a flood originating from an overflowing river. The Tugu Inscription is also distinct from the other Tarumanagara inscriptions, which are located in the outskirt areas marking the kingdom's borders. This inscription also voices stern statements of the ruling king. Experts emphasized the possibility of these distinctions as a sign that the Tugu area and its surroundings were already part of an important area for the kingdom (DKI Jakarta 1977; Noorduyn and Verstappen 1972: 298-307; Poerbatjaraka and Hadidjaja 1952: 13-15).

In the $9^{\text {th }}$ century, the Sunda kingdom emerged as one of Srivijaya's vassals; in this period the name Kalapa (Sundanese for 'coconut') started to be known as one of Sunda's port cities on the north coast of West Java. Sailors and traders from China, India, Middle East and Europe frequented Kalapa as part of their trading routes to the Spice Islands in the east and also to Banten and other ports on Sumatra's coastline. 
Some sailors' accounts referred to the settlement as Kalapa or Sunda Kalapa, and today the old port is still known as Sunda Kalapa. The Kalapa period marks the beginning from when the settlement started to become a capital city. Kalapa was fought over between the Hindu kingdom Sunda and the alliance of the Islamic kingdoms Demak and Cirebon in the east. Fatahillah, the leader of the Islamic forces was said to have changed Kalapa's name into Jayakarta but there are no historical records to confirm this. Even J.P. Coen, the founder of Batavia still used Jacatra in reference to the place after Batavia was established. While Fatahillah's conquest of Kalapa was deemed to be the birth of Jacatra, the exact year and date is still in debate. Even though the clearly weak base of the appointed date of birth, during Mayor Sudiro's period (1953-1958) the Jakarta regional government announced 22 June 1527 as the official birthdate of Jakarta.

Records show that a Prince Jayakarta was stationed in Kalapa after the conquest (Heuken 2007: 58; Heuken 2016: 26-29; Blusse 1986: 21-23; Milone 1966: 109-112). Prince Jayakarta was a relative of the Banten court, another kingdom that was conquered by Fatahillah before Kalapa. Since then, various maps have recorded the area as Jacatra, Iacatra or in other sources, Xiacatara. The victorious time ('Jayakarta' means victorious) was not for long, as the VOC arrived on the east side of Ciliwung River in 1610. The VOC's presence in vicinity, along with the British, complicated trade relations between both European powers and Banten, and created unrest until the British and Banten decided to leave the area in 1619. The VOC celebrated the "victory" by building Batavia. Jacatra fort was built and became the starting point for the Batavia citadel. This citadel then became the international trade capital of the VOC in Southeast Asia, having been taken over by the Netherlands government in 1799 , until it was conquered by the Japanese in 1942. The name Jakarta was then used by the Japanese occupation army while they celebrated the one year anniversary of the Pearl Harbor bombing.

Today, the long history of Jakarta lives on through preserved heritage buildings, centred surrounding Fatahillah square (Fig. 1), locations named after parts of the old citadel, and continuous city developments that are struggling daily against heritage preservation principles. Here in the "Kota" area (literally 'city' in Bahasa Indonesia, but also 'a fortified place' in Sanskrit), the old city area, people are living side by side with remains and ruins older than memory. Although the Monumenten Ordonannte was set in $1930 \mathrm{~s}^{1}$ and the old city revitalization began in 1972 by Governor Ali Sadikin, the inhabitants are still learning the value of the preserved heritage beyond remains of colonial oppression. This is not a unique condition for colonial cities where foreign forces came to dominate and conquer and the traumatizing history is a problematic issue. Thus, colonial history in Jakarta has not been discussed enough, along with the differences between VOC domination and rule under the Netherlands Government and also indigenous feudalism prior to the Europeans. Before what is being established for the new permanent exhibit of Jakarta History Museum (to be completed in December 2017), any perspectives on the colonial times has not gone

\footnotetext{
${ }^{1}$ Monumenten Ordonnantie 1931 (Stbl No. 238 Year 1931) is the law set by the colonial government to allow the state to establish a disciplinary action towards heritage preservation management. This law preserved colonial cities as such Jakarta and Semarang, while also allowed colonial building to survive longer. The law was first officiated in 1931 and revised in 1934 (Daud 2003).
} 
beyond material culture studies that focused on how the world trade interaction created an Indische $e^{2}$ style of art and architecture. It is important to understand that for most Indonesians, the Dutch colonial domination ran for 350 years, while in truth the period of VOC's and Netherlands Indies exploitations are separate and did not cover all areas of the Republic of Indonesia. Another point to comprehend is that for Indonesia 1945 is the year of independence while for the Netherlands it is 1948, and we also do not celebrate the "triumph" of the VOC. These postcolonial debates are a long fight between nationalistic self-respect and historical accuracy that may not ever be resolved and will not be discussed in this opportunity, but important points to remember in the process of both countries in conserving their "shared heritage". The archaeology and history of Jakarta is not just about another old port city. Jakarta, as a city, may not be as old as Beijing (founded approximately $300 \mathrm{BCE}$ ), Hanoi or Kyoto (both $8^{\text {th }}$ century CE) but it is historically older than other capitals in the region (Bangkok since 1796; Sydney since 1819 and Kuala Lumpur since early the $19^{\text {th }}$ century; Heuken 2007:16). This paper will explain the composite layers that made Jakarta as it is today. More than as a capital city, the long history of Jakarta actually formed the foundation of the country's history and became the birth place of the nation.

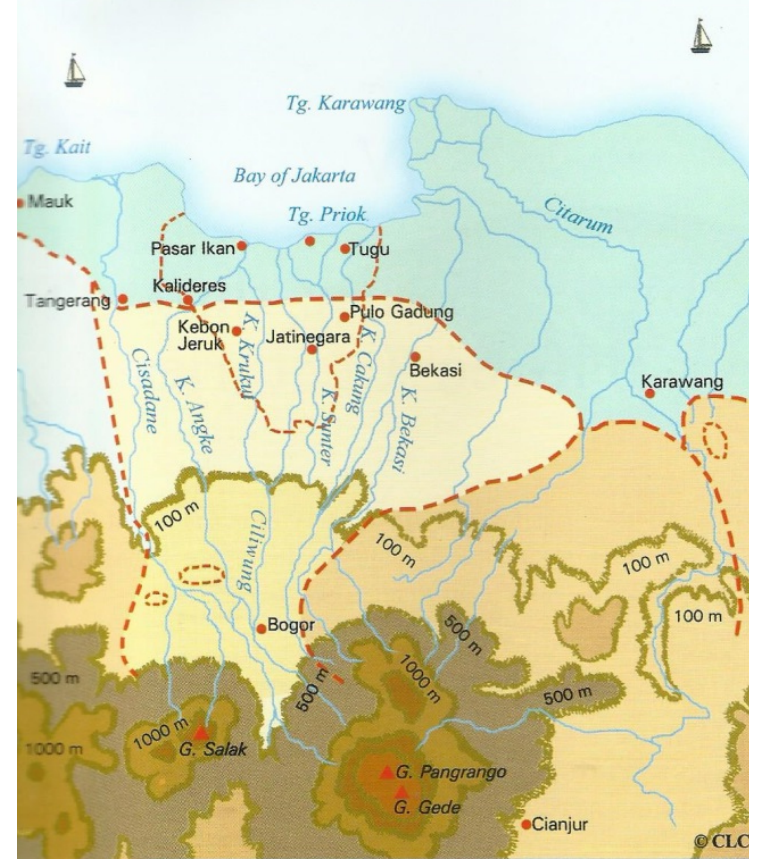

Fig. 1 The “Alluvial Fan”. Source: Verstappen (1953: 8).

Jakarta covers a vast area of alluvial lowland on the north coast of West Java that was formed from volcanoes that surround it, such as Salak, Pangrango and Gede Mountains. The alluvial sedimentation spread towards the north and shaped radial water channels that formed like a fan in the lowland (Fig. 2). This fertile alluvial fan covers today's Jakarta and its greater area that was once part of the old kingdom's boundaries. Spanning the Tangerang area in the west to Karawang in the east side, the area is filled by twelve rivers. The rivers are: Cisadane; Angke; Gebyuran;

${ }^{2}$ Indische is an abbreviation of the Dutch term Indische Nederlander meaning people from Netherlands Indies, the colonial name of the Indonesian archipelago 
Pesanggrahan; Grogol; Krukut; Ciliwung; Sunter; Buaran-Cakung; Cileungsi Bekasi; Cikarang and Citarum. According to Theo Verstappen's calculation, this alluvial fan was shaped since 5,000 years ago (Verstappen 1953: 85-90). So far among these rivers, Ciliwung is the one with the most prehistoric sites, which is the largest river in this area in comparison to the other rivers in the greater Jakarta area.

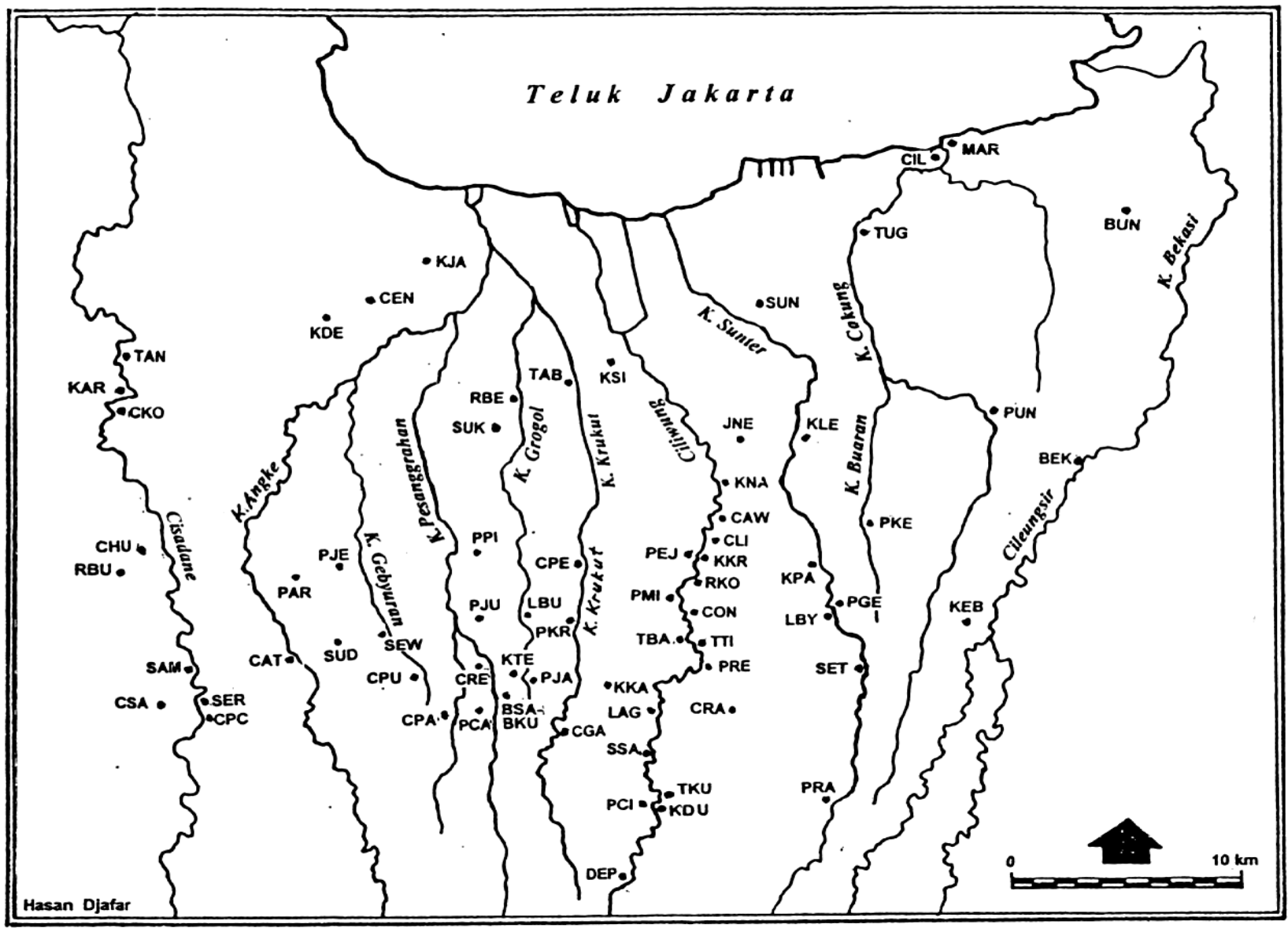

Fig. 2 Distribution of Prehistoric Sites in Jakarta and surrounding areas. Source: Djafar (1985:61).

The distribution of Neolithic findings (Figs. 4-6) in the greater Jakarta area shows the occupation of the alluvial fan by a society who lived an agricultural lifestyle around the fertile river banks (Fig. 3). One of the great findings of this cultural layer is a burial of a male and female found in Batujaya, near a site where archaeologists also found a later Buddhist temple complex. This couple was found buried with burial goods consisting of Buni style pottery and metal work in the form of weaponry and gold bracelets (Djafar 2006 and 2009). 


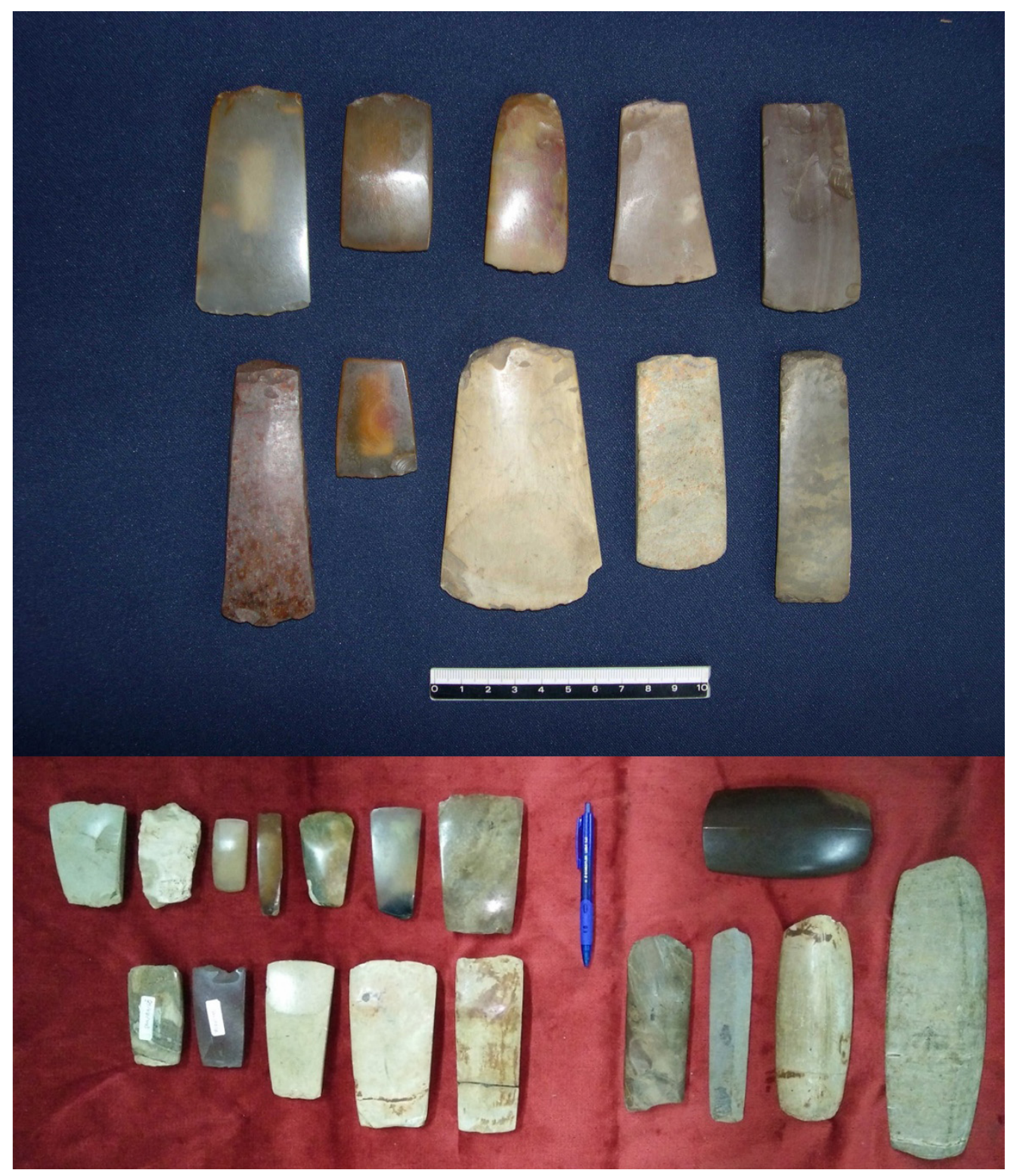

Fig. 4. Above: Stone tools found from Buni site, Bekasi. Source: Djafar, 2006. Below: Stone tools found from sites in Jakarta. Source: Annissa Gultom 2017. 

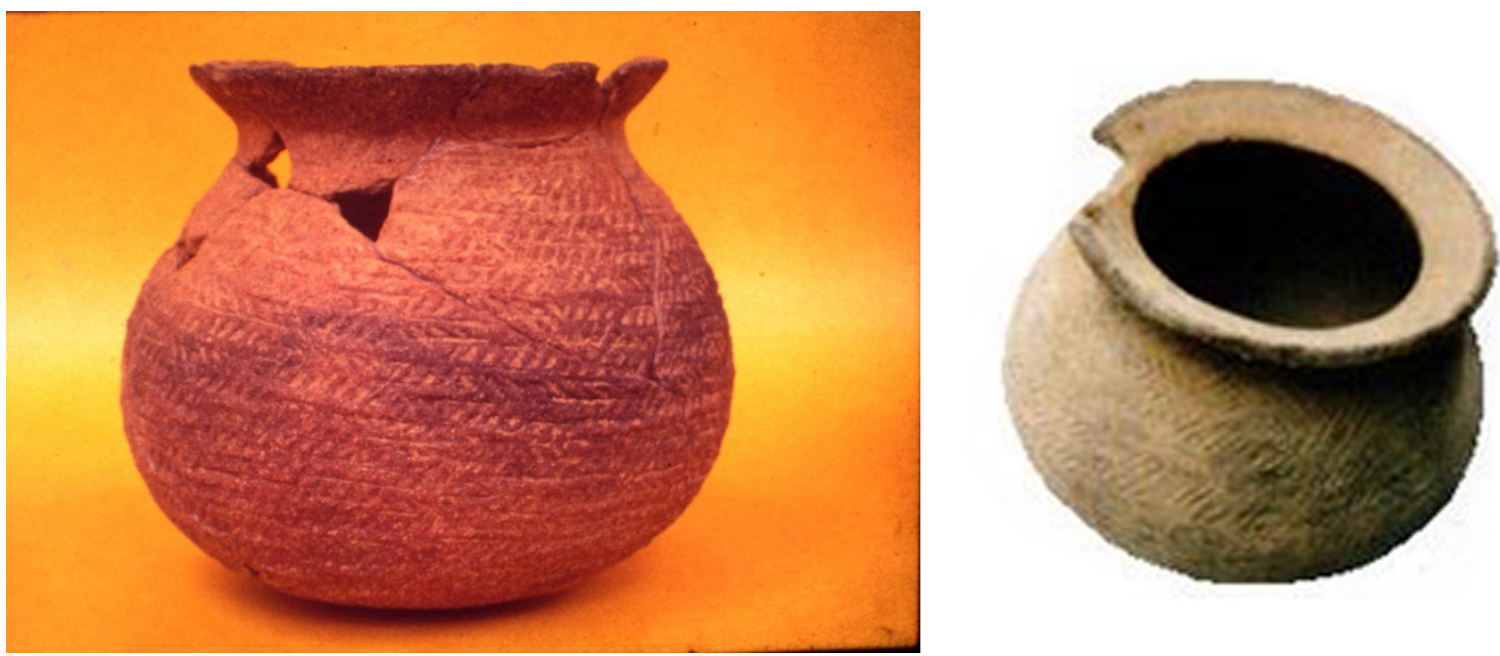

Fig. 5 Decorated pottery found in Condet site, Balekambang, Cililitan, East Jakarta. Excavated by the Office of Museum and History (Dinas Museum dan Sejarah) of Jakarta in 1979, now collection of the Jakarta History Museum. Source: Hasan Djafar (left) and Jakarta History Museum (right).
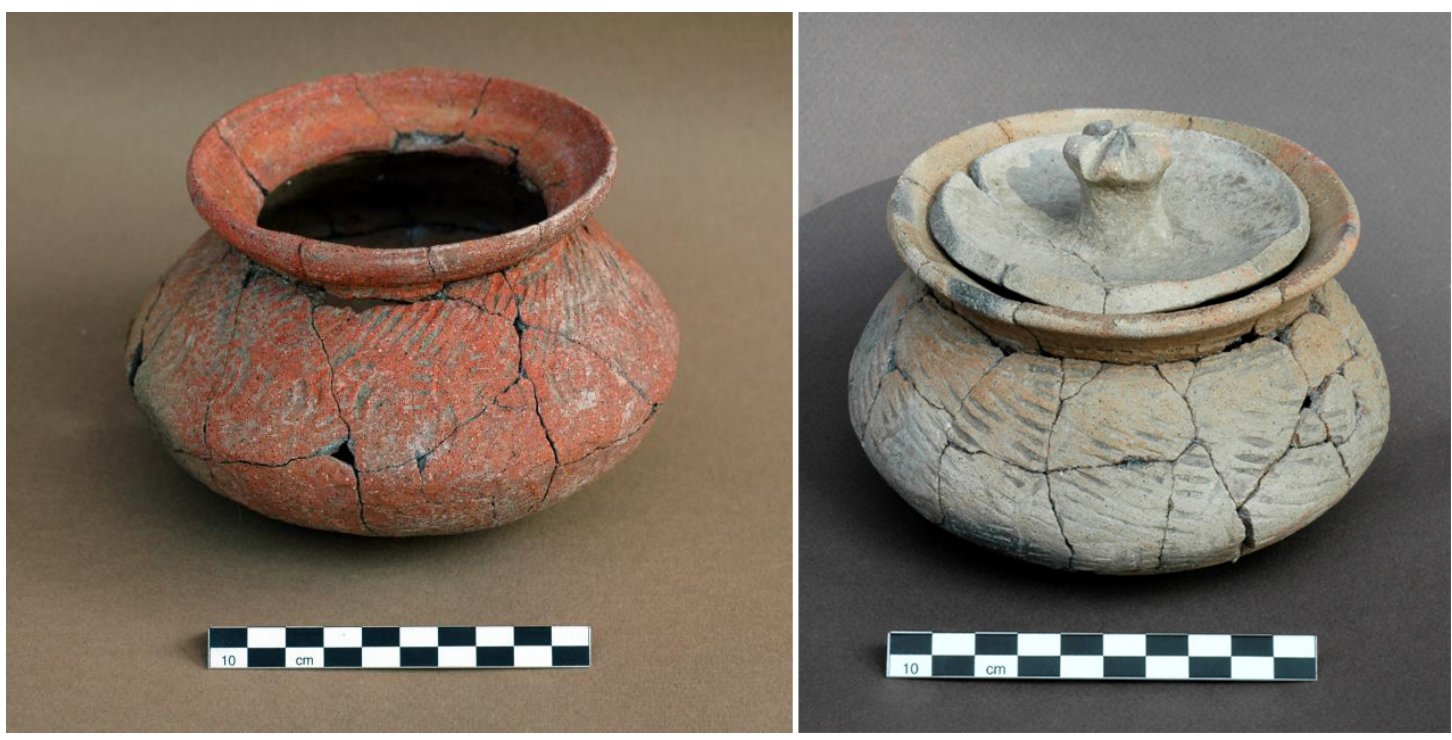

Fig. 6 Two decorated pots (reconstruction result), grave goods from Segaran II A site (Unur Lémpéng), Batujaya. Excavated by the National Centre of Research and Development of Archaeology with EFEO in 2005. Source: Widianto 2006. 


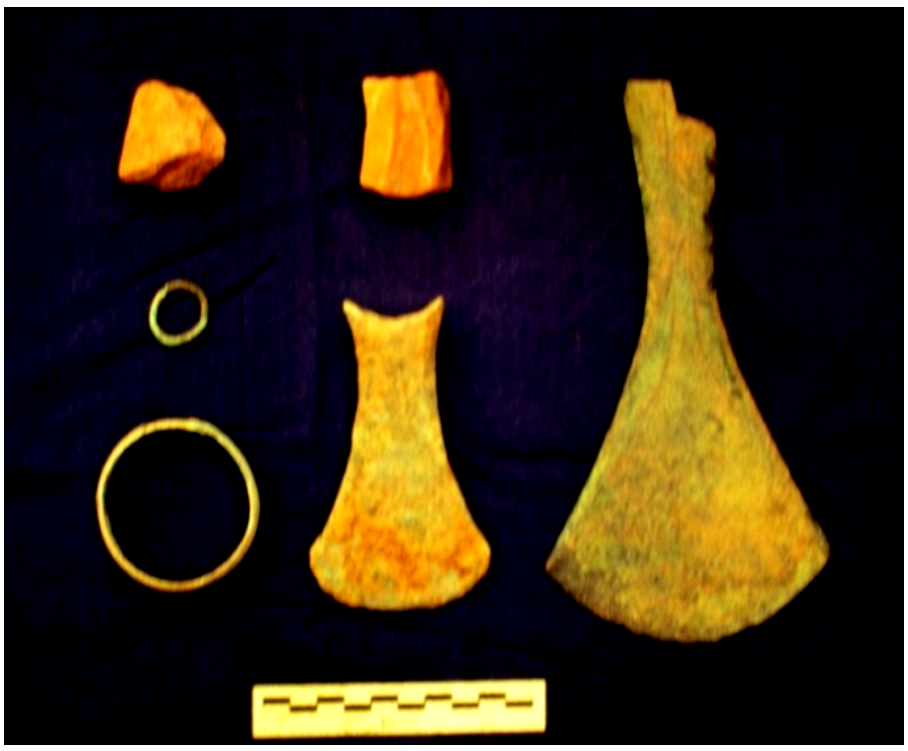

Fig. 7 Artefacts from the excavation by the Office of Museum and History (Dinas Museum dan Sejarah) of Jakarta from the metal workshop site in Pejaten, Pasarminggu, Jakarta Selatan in 1974. The finds consist of two bronze axes, a bronze ring, a bronze bracelet and two terracotta fragments of a bronze axe mould. Collection of Jakarta History Museum. Source: Djafar 1988.

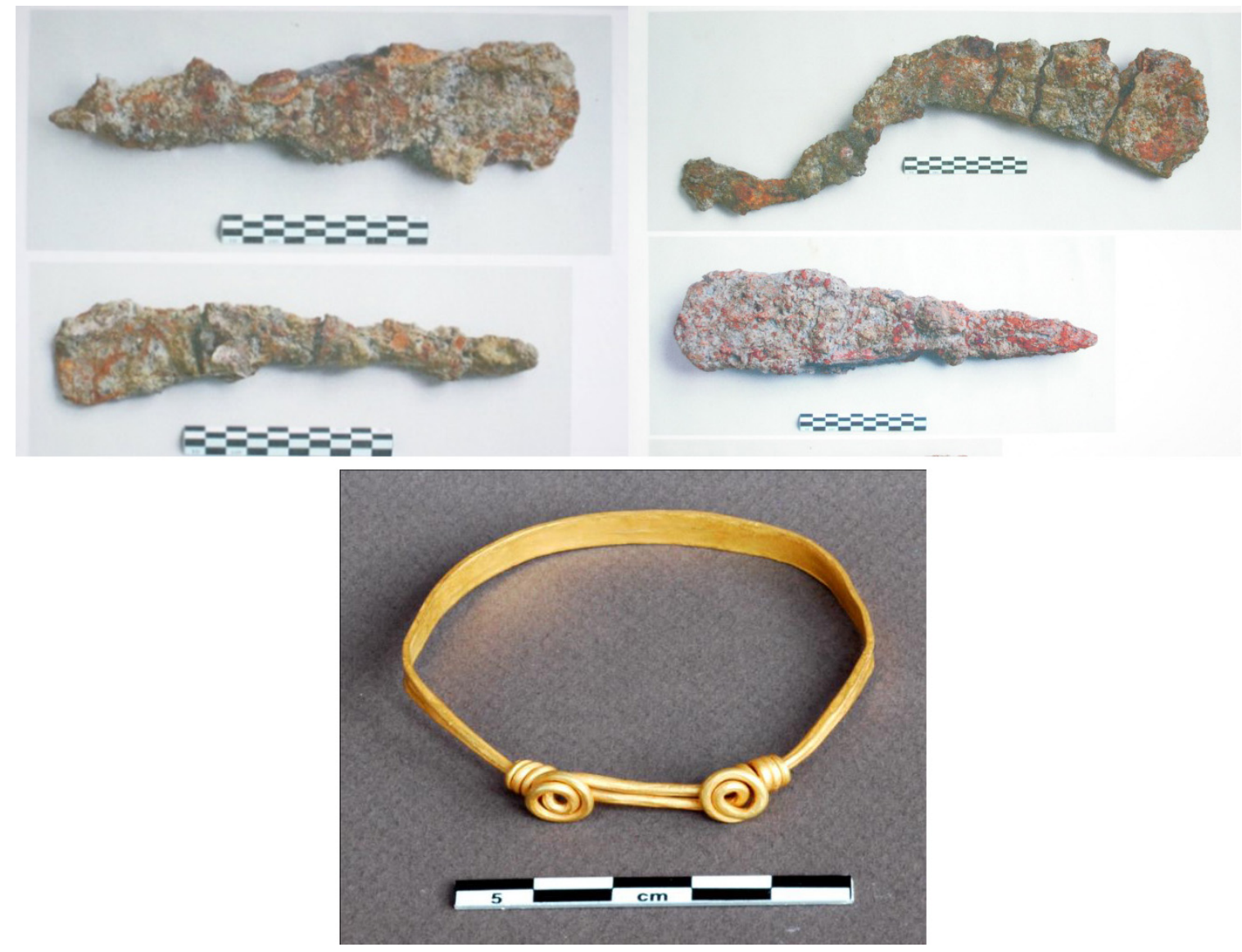

Fig. 8 Above: Metal remains found with by the male mongoloid from metal-era found in Batujaya, Karawang Source: Widianto, 2006. Below: Gold bracelet Source: Private collection of Bambang Budi Utomo 2012. 
People who occupied this area in prehistory lived an agricultural lifestyle, hunted and fished, and developing weaved items and pottery, and later on, developed metalworking. This period in Jakarta occurred between $3500 \mathrm{BCE}$ to the early centuries. No older prehistoric remains have been found in the area. Another prehistoric periodization that has also been found in Jakarta greater area is the metal period. Based on $\mathrm{C} 14$ analysis of cinder found among metal artefacts (Fig. 7) from a metal workshop site in Pejaten, Pasarminggu, south of Jakarta, the metal period in greater Jakarta originated from around 1000 - 500 years BCE (Djafar 1985:56; Djafar 2006: 14). A gold bracelet was also found worn by one out of two burials in Batujaya; the male specimen was also holding an iron weapon and like his female companion was accompanied with grave goods consisting of Buni ceramics (Fig. 8). Widianto (2006) by referencing Soejono's publication in 1984 concluded from remains found there and in a few places along the north coast of Bekasi and Karawang that these early occupants of the alluvial fan area were mongoloids.

In the same site as the gold bracelet-wearing man, on a younger cultural layer, the Batujaya temple complex attests to the length of Tarumanagara's influence.

Archaeologists found remains of a temple complex that may have been active during the same period as the Tarumanagara kingdom $\left(5^{\text {th }}-8^{\text {th }}\right.$ centuries CE) with findings as old as $2^{\text {nd }}$ century CE (Fig. 9). Artefacts found in this site and nearby also included rouletted pottery imported from India and two Hindu temples with Pala kingdom-style Vishnu statues (Fig. 10), showing the international connections to the area. 


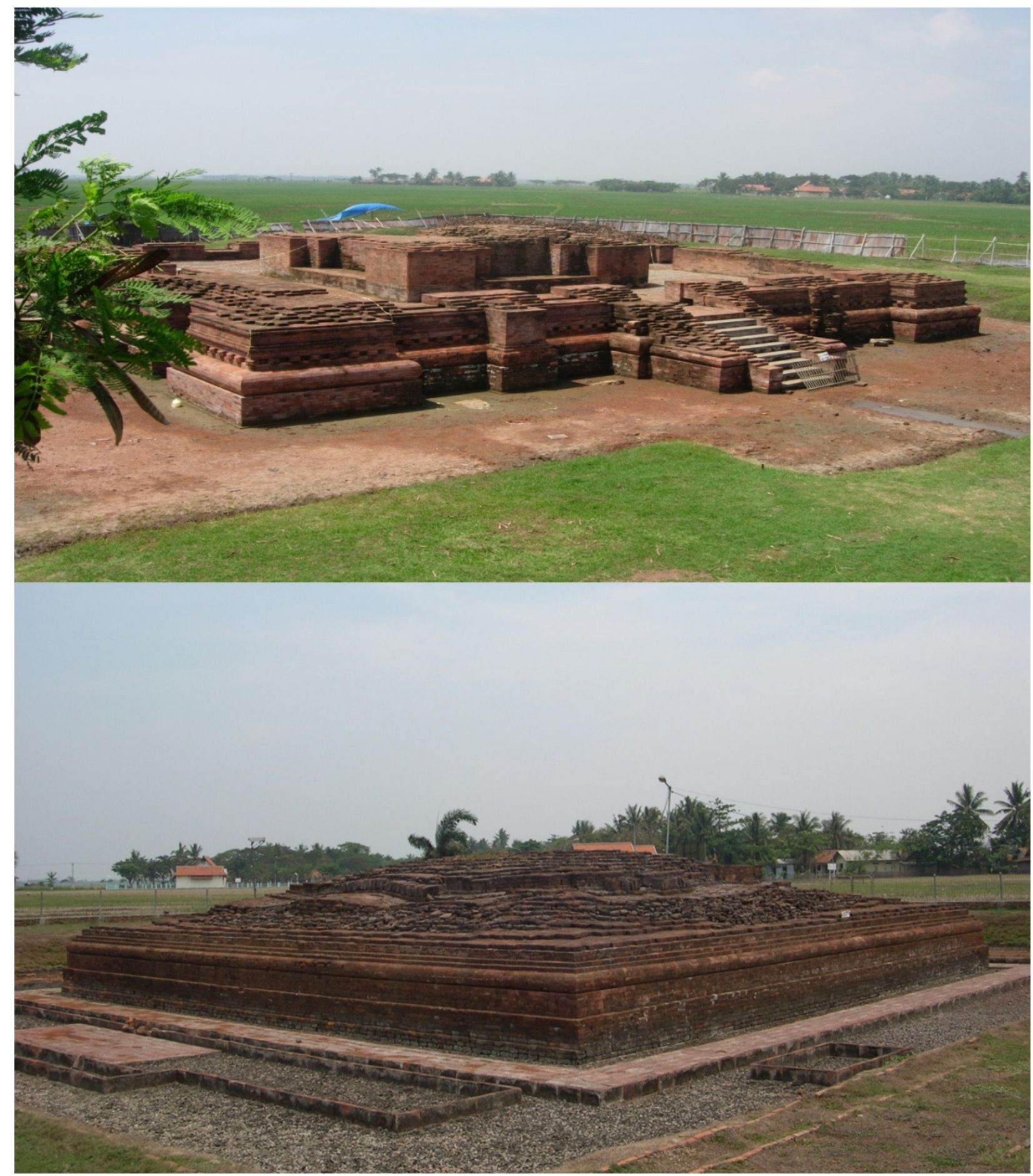

Fig. 9 Buddhist Temples Complex in Batujaya, Karawang. Top: Segaran I (Candi Jiwa); Below: Candi Segaran V (Candi Blandongan). Source: Hasan Djafar 2010. 

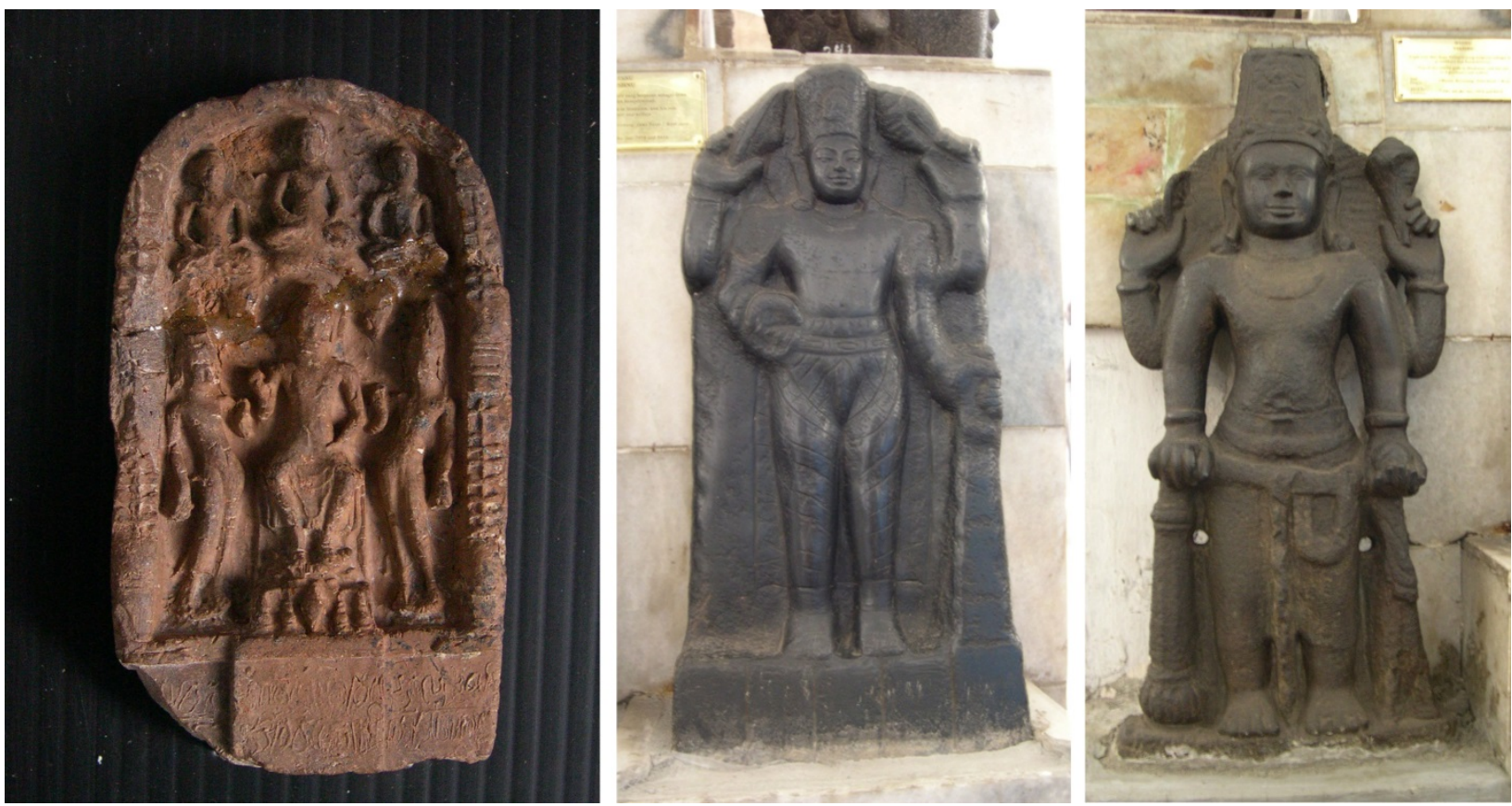

Fig. 10 Sculptures found from the Tarumanagara period. Left: Terracotta Buddhist Votive Tablet Candi Segaran V, Batujaya, Karawang. Size: 6 x 4 x 0.50 cm. Source: Hasan Djafar 2004. Middle: Statue of Visnu Cibuaya I; Right: Statue of Viṣnu Cibuaya II, both are in the Pala art style of 7th-8th and 8th-9th CE. Museum Nasional, Jakarta. Source: Hasan Djafar 1990.

Citarum River is quite special as its name shows deep connection with the Tarumanagara kingdom. Both places include the name "tarum" which means blue or indigo in Sundanese, while "nagara" is Sanskrit for state/country and "ci" in the beginning of Citarum is Sundanese for "river". It is surmised that there was indigo dye used in the older days and the natural waste flowed along the river. It makes sense that Tarumanagara occupied the fertile land surrounding this third longest river in Java. The river provided the substances needed to create a flourishing civilization while also giving access to the interior from the sea in the north. The extent of the Tarumanagara kingdom's rule on the alluvial fan topography of West Java surrounding this river is marked by Tarumanagara's artefacts found in sites located in the north coast of Jakarta (Tugu inscription) where Sunda Kalapa was once situated, and also in sites located in the west (Cidanghiyang inscription), south (Ciaruteun, Kebon Kopi I and II inscriptions) and east of Jakarta (Cibuaya and Batujaya sites).

Other than the temples, Tarumanagara inscriptions were found in sites surrounding the greater Jakarta area hinting at the reaches of its power. Tarumanagara inscriptions were found in the east of Jakarta (in Cidanghyang, Lebak, Banten province); south of Jakarta (Kebon Kopi and Ciaruten, both in Bogor) and the most important one in the north of Jakarta, the Tugu Inscription (Kampung "Batu Tumbuh", Tugu, North Jakarta). The Tugu Inscription was made to commemorate a canal that changed the course of a river and drained a coastal area for agriculture and settlement. The Tugu stone was prepared before it was ready to be inscribed and was formed into an egglike shape. Its writing and a shape of what it looks like a special shaft was then inscribed around the stone. Other Tarumanagara inscriptions had only a part of the stone's surface that was prepared by being flattened and polished to have text or shapes (elephant feet, human feet, typography) carved on it. These inscriptions talk 
about the great king Purnawarman of Tarumanagara as the ruler. While the Tugu Inscription commemorates the achievement of the king's father along with an elaborate regal looking shaft carved on it (Fig. 11). The locations of where the inscriptions were found are in outer areas of greater Jakarta area, usually in the vicinity of megalithic remains or prehistoric sculptures. Some hypothesize that these inscriptions may be situated in outer areas where the kingdom had been bordering with areas ruled by people from the metal era civilizations. Tugu is in north coast of Jakarta, near the Tanjung Priok international port by the Cakung River, near the former cost line (Fig. 12). These distinctions make us wonder whether the area now known as Jakarta has already been a cosmopolitan city even before the name "Kalapa" was historically documented.
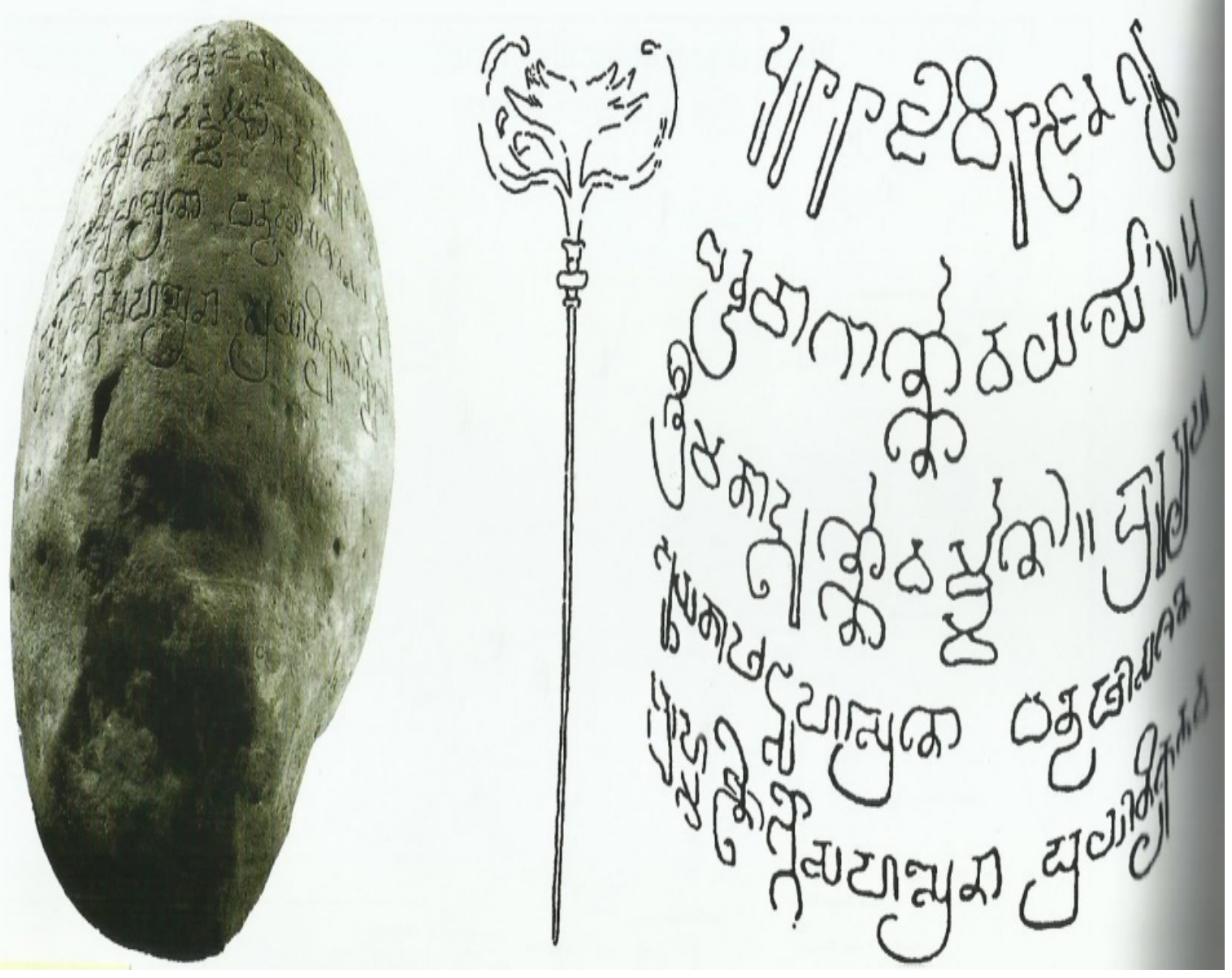

Fig. 11 Tugu Inscription of Tarumanagara. Source: Heuken 2011. 


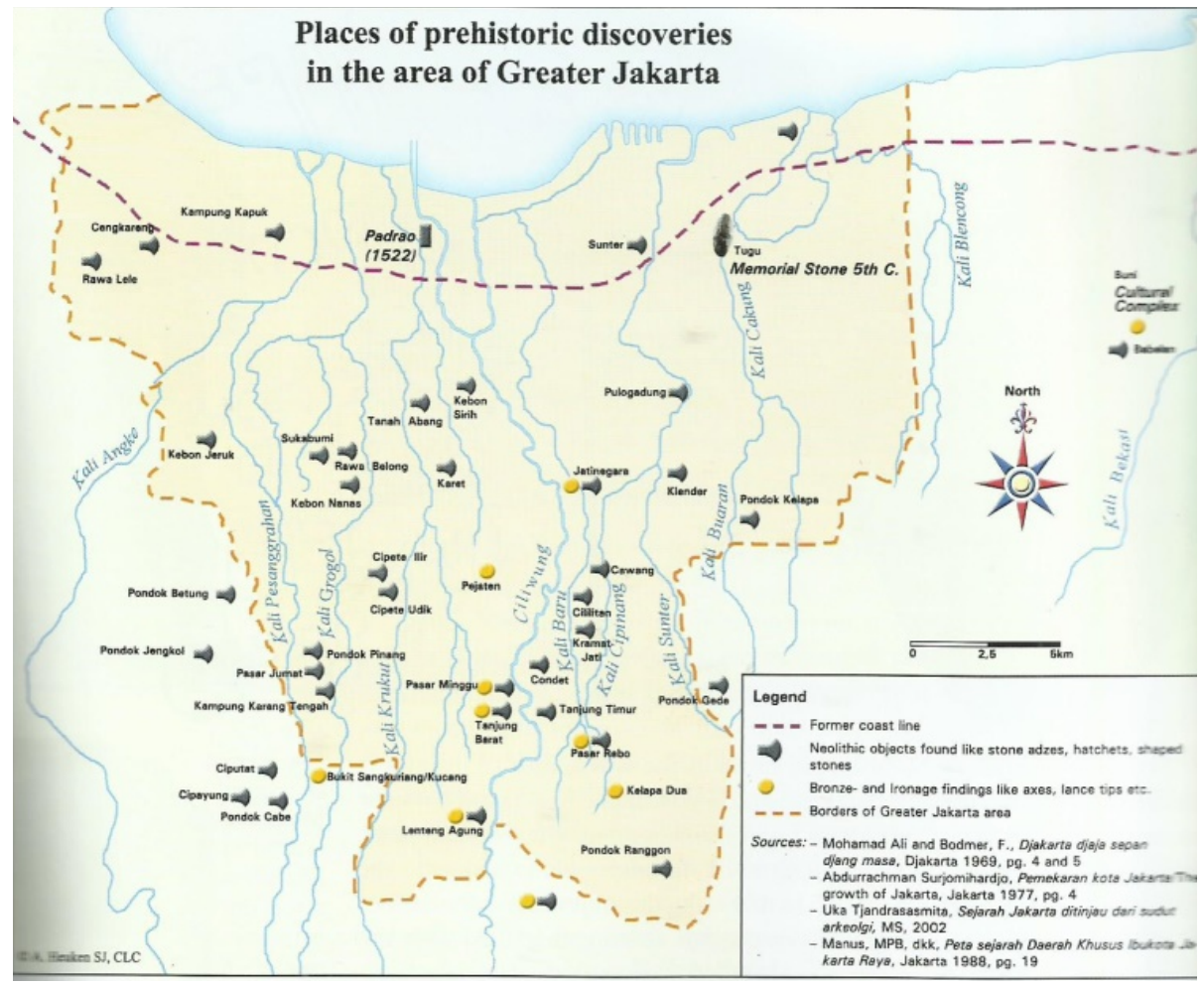

Fig. 12 Location of the Tugu Inscription site. Source: Heuken 2011.

Chinese historical sources documented the existence of people in the west part of Java in $5^{\text {th }}$ century CE, and also about King Purnawarman and the Tarumanagara kingdom in the $6^{\text {th }}$ century CE. The Chinese Buddhist monk Fa Xian reported in his book FoKuo-Chi (written in $414 \mathrm{CE}$ ) that he stayed on the island of Ye-Po-Yi (the Chinese spelling of Javadvipa), most probably located on the western part of Java, for six months, from December 412 until May 413. He reported that the Law of Buddha was not much known, but that the Brahmans (Hinduism) flourished, and heretics (animists) too. Another resource documented the visit of Tarumanagara embassy to the Chinese court. The annals of the Sui dynasty mentioned that the king of To-LoMo (Taruma) had sent diplomatic mission, which arrived in China in 528 and 535. It was mentioned that the kingdom is located far south of China. Another visit from ToLo-Ma was also mentioned in the year 666 and 669 in the annals of Tang Dynasty (Coedès 1968: 54).

Sunda (932 CE) is a Hindu kingdom that emerged after Tarumanagara (Fig. 13). The oldest record that mentioned the name Sunda is the Kebon Kopi II Inscription that was found in Bogor, not so far from where a few inscriptions of Tarumanagara are located. The kingdom produced high-quality black pepper and ruled the western part of West Java province, Jakarta and today's Banten province. Sunda has quite a few ports along its north coast, from Banten up to Cirebon, but the most important ones were Banten and Kalapa, as both were the most frequented by sailors to be mentioned in the records. A Chinese book called "shun-feng hsiang-sung" from about 1430 AD mentioned about route taken ships that voyaging along the north coast of Java. After the ships reached Kalapa, they then followed the coast (past Tanjung Indramayu), finally steering to reach Cirebon. Ships from Banten proceeded eastward along the north coast of Java, past Kalapa, past Indramayu and past Cirebon. According to this 
source the port of Sunda was located west of Kalapa and later identified as port of Banten. European explorers also reported the existence of the Sunda Kingdom. Tomé Pires from Portugal wrote in his report "Summa Oriental (1990/1513-1515):

Some people affirm that the Sunda kingdom take up half of the whole island of Java; others, to whom more authority is attributed, say that the Sunda kingdom must be a third part of the island and an eight more. It ends at the river chi Manuk (Cimanuk). The river intersects the whole island from sea to sea in such a way that when the people of Java describe their own country, they say that it is bounded to the west by island of Sunda. The people hold that whoever passes this strait (the river Cimanuk) into the South Sea is carried off by violent currents and unable to return (Heuken 2002: 47, 53).

The Portuguese report is dated from a later period of the kingdom, shortly before its fall to forces of the Sultanate of Banten (Heuken 1999). Tomé Pires continues about the Sunda Kingdom's abundant wealth shown from how many horses, elephants, gold, natural resources and spices like pepper and tamarind, and also rice, fruits and other trade commodities (Heuken, 2002: 47-50, 54-56). The account also mentioned places of where the king resides and Sunda's ports:

The city where the king is most of the year is the great city of Dayo. The city has well-built houses of the palm leaf and wood. They say that the king's house has three hundred and thirty wooden pillars as thick as a wine cask, and five fathoms $(8 \mathrm{~m})$ high, and beautiful timber work on the top of the pillars, and a very well-built house. The city is two days journey from the chief port, which is called Kalapa (Heuken 2002: 48, 54-55).

Sunda has six ports: Bantam (Banten), Pontang (Pontang River near Banten), Chegujde (Cigede/Cisadane River), Tamgara (possibly the origin of Tangerang), Calapa (Sunda Kalapa or Jakarta) and Chi Manuk (Cimanuk). Among them, Calapa is mentioned as the most important one:

The port of Calapa is a magnificent port. It is the most important and best of all. This is where the trade is greatest and whither they all sail from Sumatera, and Palembang. Laue, Tamjompura, Malacca, Macassar, Java and Madura and many other places. These nations trade also in the other ports. This port is two days' journey from the city of Dayo where the king is always in residence, so that this is the one to be considered the most important. It is almost joined to the land of Java, except that Chi Manuk is between them, and from Chi Manuk here takes a day and a night with favourable wind. The merchandise from the whole kingdom comes here to this port. This port is well governed; it has judges, justices, clerks. They say that [it is] already (laid down) in writing (that) whoever does so and so will get so and so by the law of the kingdom. Many junks anchor in this port (Heuken 2002: 50-52; 57-58).

The account showed how the Portuguese had frequent interactions with the Sundanese either in the Sunda areas or in Malaka where the first Portuguese colony in Southeast Asia was founded. One of the most important things to be noted from this observation is that name of Sunda ports, from the west to the east by mentioning Kalapa, and not 
Sunda Kalapa. Later on, Banten and Tangerang would be part of Banten Kingdom, while Kalapa remained as Sunda's main port. Some records on maps show "Kalapa" or "Sunda Kalapa" (Fig.14). The name Sunda Kalapa is the one that stuck on people's memory until today even though Sunda Kingdom no longer exists. The old port in Jakarta is now still called "Sunda Kalapa".

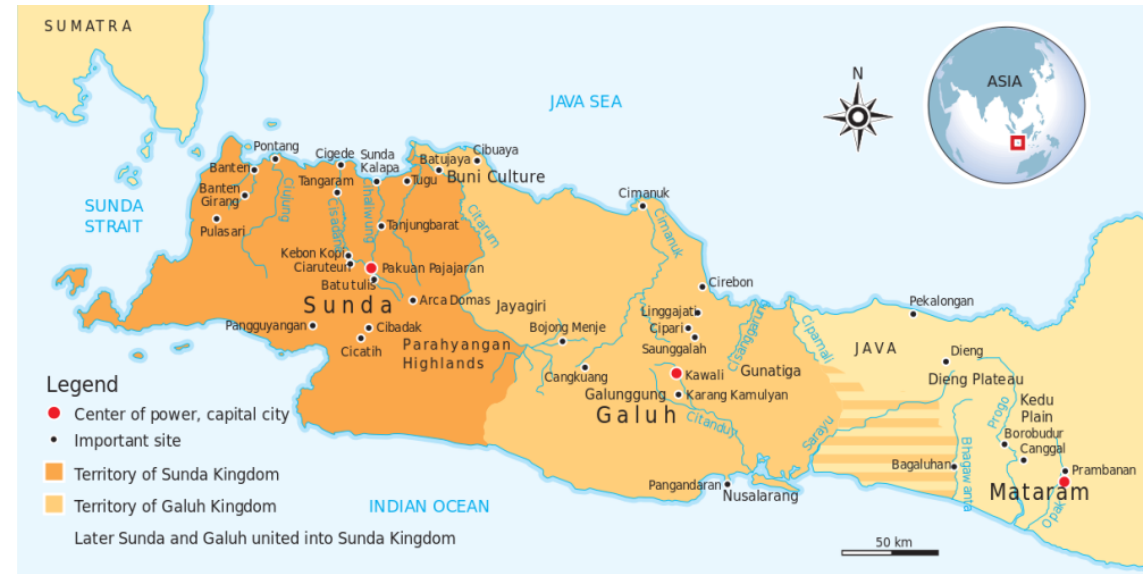

Fig. 13 Sunda Kingdom and surroundings. Source: Gunawan Kartapranata, Wikimedia Commons 2009.

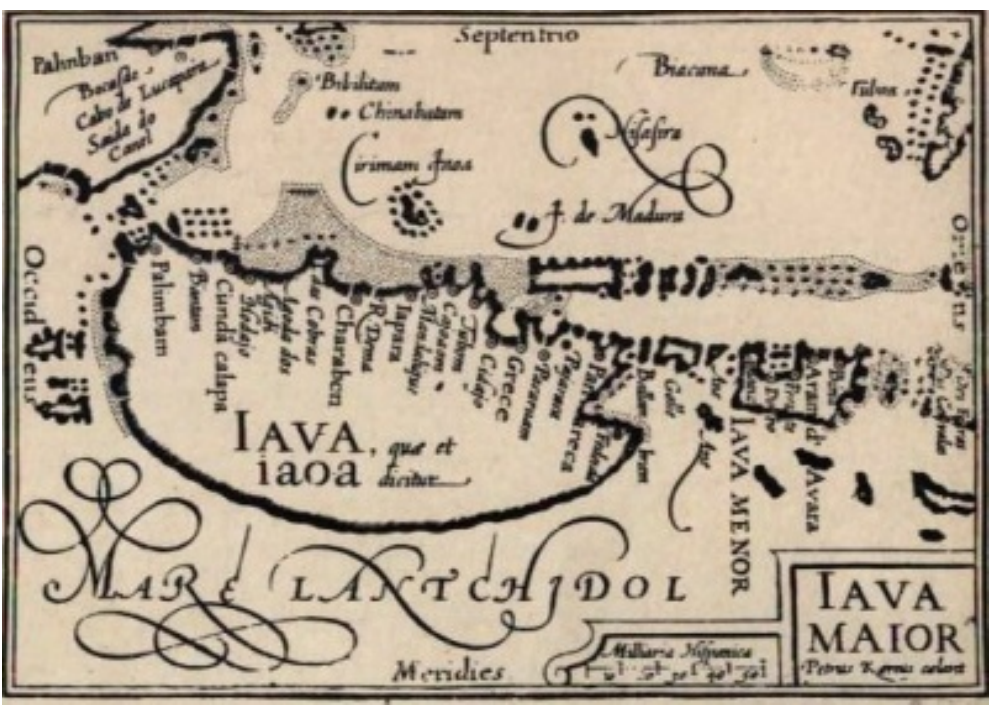

Fig. 14 Cunda calapa (Sunda Kalapa) documented in Portuguese map along with other important ports on north coast such as, Cherebon (Cirebon); Iapara (Jepara); Tuban; Grece (Gresik). Source: Heuken 2007.

\section{From Kalapa to Jacatra}

The importance of Kalapa in Sunda is not only shown by the maps from the age of exploration, but also as the focus for conquering Sunda. The capital of Sunda, Pakuan 
Pajajaran is located in the interior (Bogor today), but the port was an important hub for the kingdom to stay connected with the international trade.

Sunda anxiously reached out to Portuguese support against the rise of Islamic power in the east. In $1475 \mathrm{CE}$, Demak became the first and largest Islamic kingdom in the north coast of Java and in its expansion succeeded in destroying their former rulers the Majapahit kingdom. Demak was located in central Java, east of the Sunda kingdom. As a result of this event, only Blambangan in the eastern edge of Java, and

Sunda in the western part remained Hindu. In 1482, the Sunda Kingdom lost one of its important ports, Cirebon. On 2 April 1482, Sunan Gunungjati, the ruler of Cirebon, stated that Cirebon would no longer send tribute to Sunda Pajajaran and proclaimed independence. Sunan Gunung Jati later established the Sultanate of Banten, which become a menace for the Hindu Sunda Kingdom.

Around the same time, Cirebon became an Islamic kingdom and had ties with Demak. Both kingdoms joined forces to conquer Sunda by targeting Kalapa. Under this pressure, Sri Baduga, the king of Sunda, contacted the Portuguese in Malaka in 1512 and 1521 to develop a treaty that would allow the Portuguese to build a military fort in Kalapa. This treaty was set in stone, inscribed in what it is called as the LusoSundanese Padrão. The Padrão is an inscribed stone erected in a place whenever the Portuguese found new land and on this occasion the padrão symbolized the location on which the Portuguese were allowed to build a fortress at the mouth of the Ciliwung River (Figs. 15-16).
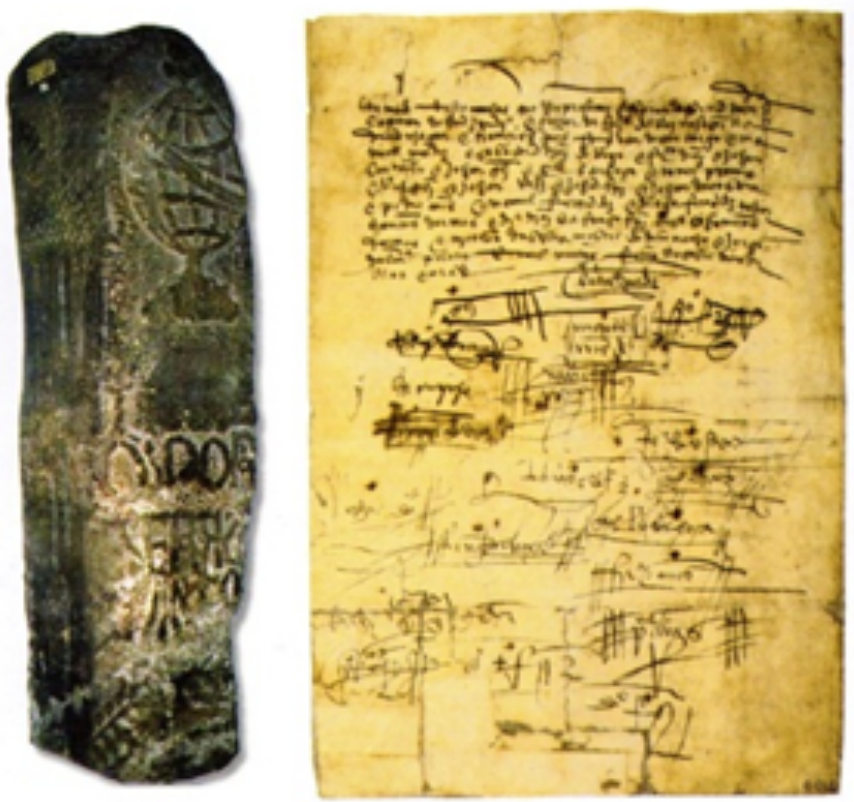

Fig. 15 Remains of the Sunda-Portuguese treaty in 1522. Left: the Luso-Sundanese Padrão; Right: the last page of the treaty between Sunda and Portuguese in 1522. Source: Heuken 2007. 


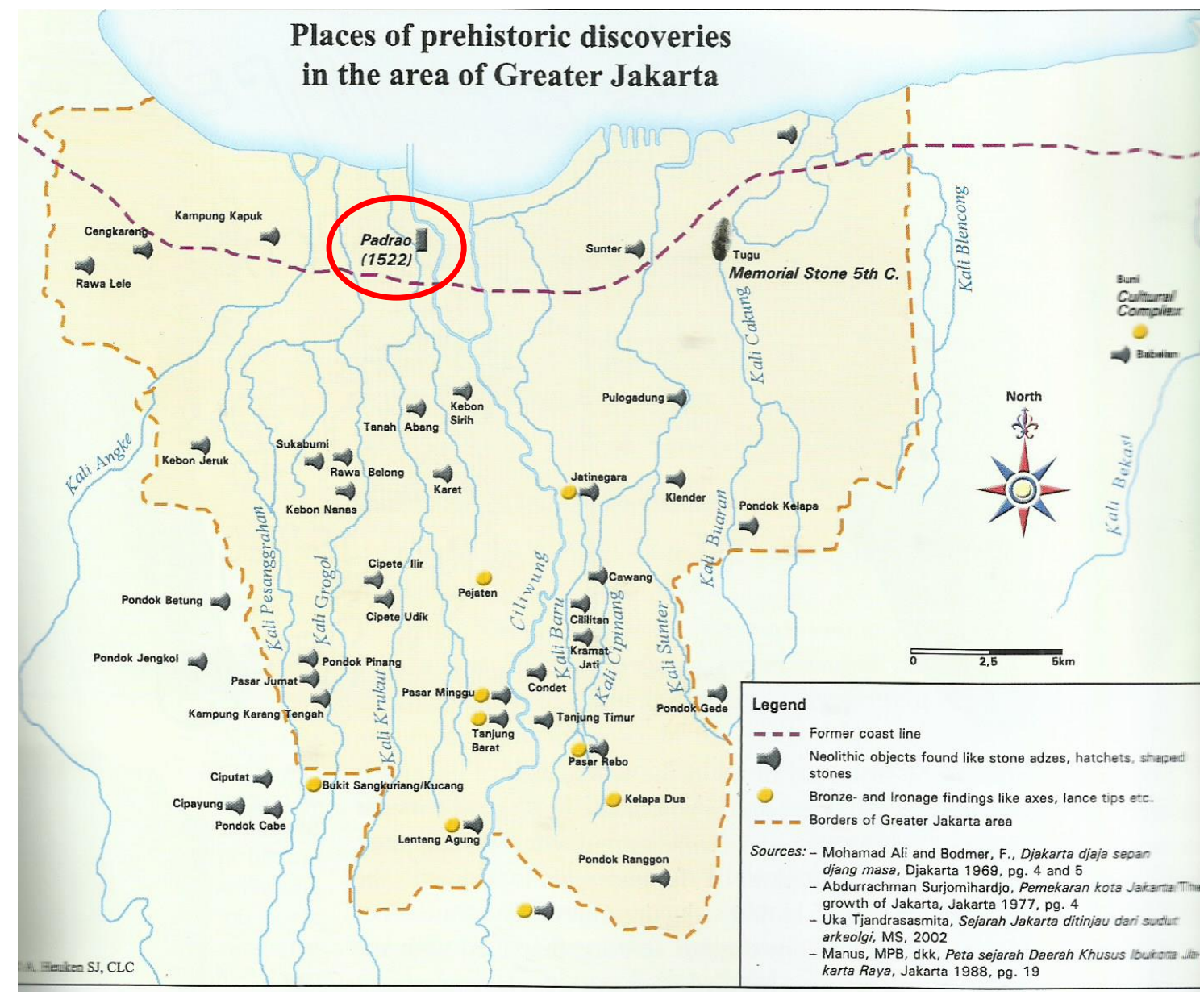

Fig. 16 Location of the Luso-Sundanese Padrão. Source: Heuken 2007.

Because of troubles in their other colony in India, the Portuguese failed to return to Kalapa until 1526, the same year that Demak conquered Banten and then followed by pushing into Kalapa. In 1527 Kalapa fell to the Islamic forces that was said to be led by the almost-mythical general, Fatahillah $(1487-1570)^{3}$. Kalapa then became a satellite of the Banten Sultanate. Unconfirmed sources mentioned that he changed the name Kalapa into "Jayakarta", which means 'victory'. This event is taken as the mythical story of the birth of Jakarta. Foreign sources record the place as Iacarta (Fig. 17), or Xacatra or Jacatra. This name may have originated from prince Jayakarta's name, a Banten-related prince who was assigned to manage Kalapa. But at this point, Banten was already conquered by Fatahillah before he moved to Kalapa. The Islamic domination in the area started to diminish when European traders began to move from Banten to Kalapa. The British was the first while the VOC built a wooden godown and houses on the east bank of the Ciliwung River in 1611. The Dutch then developed it into Fort Jakarta (Fig. 18).

\section{Batavia, a planned citadel}

In 1618 the tension between the ruler of Jayakarta, Jayawikarta, the British and the Dutch increased. With the support of the British, the Dutch fortress was besieged and the newly-appointed Governor General, Jan Peterszoon Coen escaped to the Moluccas

\footnotetext{
${ }^{3}$ Also known as Paletehan or Fadillah Khan
} 
to seek support. In the following year, Banten, who was not happy with the agreement between Jayawikarta and the British, started a three-way conflict which in turn became an opportunity for Coen. Coen returned in the same year with reinforcements and burned Jayakarta to the ground and expelled its population. In 1619 the VOC planned a new castle called Batavia Castle. Coen proposed the name Niew Hoorn (after the city of Hoorn, his birthplace) but it was not granted. The board of VOC prevented his proposal and chosen the name Batavia instead. It was named after the Germanic tribe of the Batavi, the ancestors of the Dutch people who inhabited the Batavian region during Roman period. The official naming ceremony took place on 18 January 1621. Batavia Castle was the start of the fortified city of Batavia.

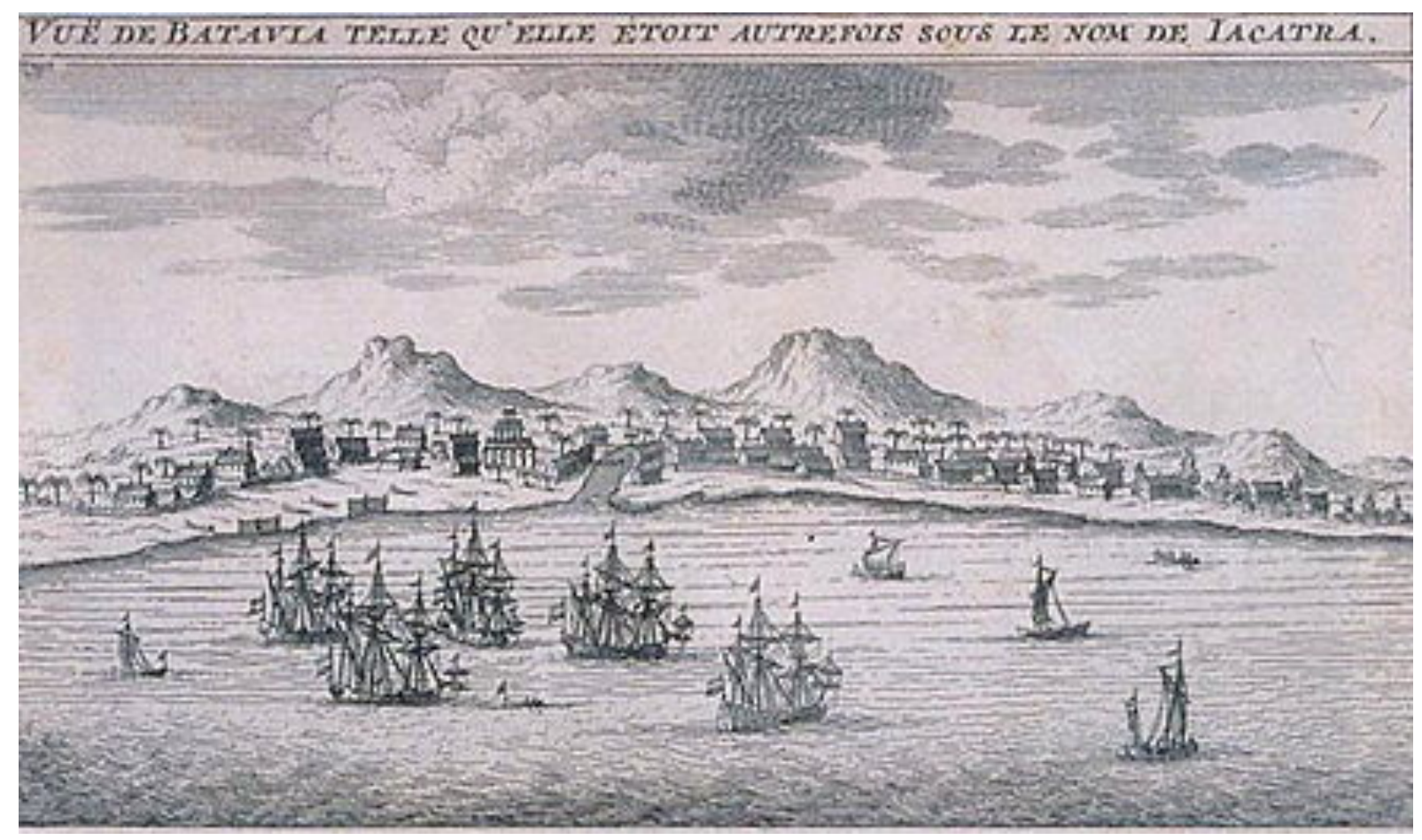

Fig. 17 View of Batavia under the former name of Iacatra. Original engraving on paper part of Koninklijk Instituut voor de Tropen/Tropenmuseum collection. Source: Tropenmuseum, public domain. 


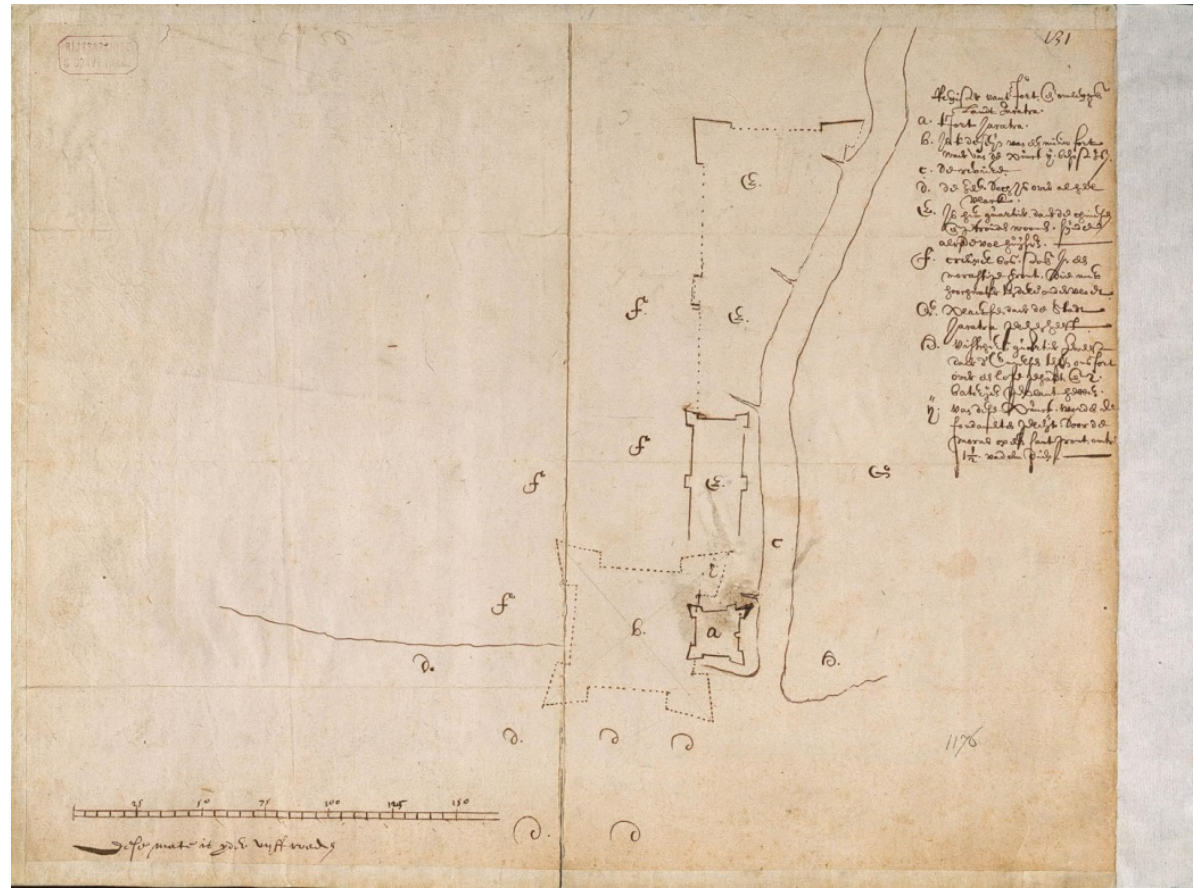

Fig. 18 Plan of Fort Jacatra, circa 1619. Source: Dutch National Archives, public domain.

Coen's idea was to build a grid-system planned city that was then suited with the topography. The grid plan he referred to is as such the ideal port plan by Simon Stevin that was constructed along geometric lines with a gridiron as the leading principle. This plan at the time was considered as the contemporary notions of the 'ideal' city (Stevin in Kwanda 2011). Simon Stevin was a famous mathematician in his time but also a fortress builder and town planner. The concept became the basic blueprint of the city's development with its grid and canal system (Fig. 19), starting in 1620 from the east side of Ciliwung River by the east wall of Fort Jakarta.

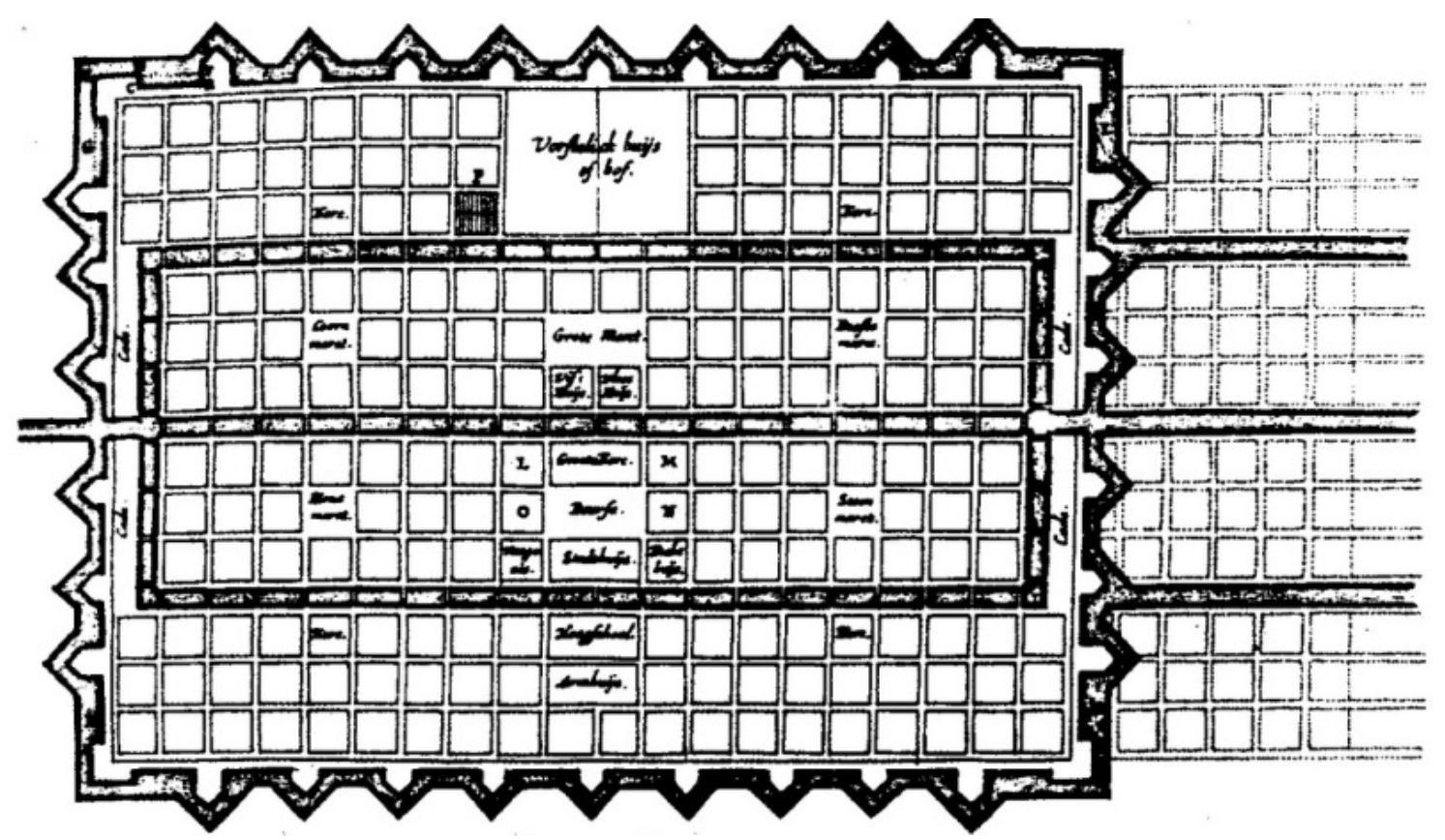

Fig. 19 Simon Stevin's idea of an ideal grid city plan. Source Heuken 2011. 
J. P. Coen, an accountant who worked his way up the ranks of VOC became one of the big names in VOC history and is deemed to be the founder of Batavia. Yet for Indonesians, the birth of Batavia is not celebrated as the birth of Jakarta; this event is instead attributed to Fatahillah's renaming of Kalapa into Jayakarta in 1527. Opposite point of views on historical events are thus inevitable.

The construction of the Batavia citadel started from the east side by continuing along the east wall of Fort Jacatra, towards south and then continuing the wall over the west part of the river. This development took decades to finish and even included straightening a part of Ciliwung River so it became a spine of the city. In 1622 some parts of the east wall were finished, then in 1632 the river was straightened and a moat that surrounded the city was completed in 1632. In 1635 the grid plan on the west side of the river was built and then completed in 1650 (see Breuning 1954).

As the capital of the VOC, Batavia became a very busy port city. A few small islands off shore of Jakarta Bay (currently known as Thousand Islands) even once functioned as a central shipyard that gave 24-hour service for the ships that went in and out of the port. Onrust, one of the islands, was named as such for its restless activities, always in the rush of servicing ships.

The citadel development continued along the international growth of the VOC's economic dominance. In the age of exploration, competition was intense between Spanish, British (EIC), Portuguese, French, Swedish and the Dutch. The Dutch with their VOC dominated the spice trade by physically dominating the Spice Islands and made Batavia as one of the main hubs for international trade.

Until the second half of the $17^{\text {th }}$ century, VOC ships had to stop in Batavia before continuing the trip from Europe to Asian countries as well as from Asian countries to Europe. This ensured that Batavia had important relationships with all VOC trading posts in Asia and the Netherlands until the 18th century when VOC trading posts in China, Ceylon and India have direct contact and shipping line with the Netherlands. There was even documentation of frequent communication with the foreign international commerce hubs in Ayutthaya, a Siamese Kingdom.

\section{Kalapa - Jacatra - Batavia - Jakarta: Growth of a city}

The occupancy of the area started along the banks of rivers that flowed on the alluvial lowland. More complex civilizations grew along the bigger rivers, as they allowed more access between the sea and the interior. Tarumanagara's Tugu Inscription was the oldest indication of how the area may have been cosmopolitan long before the time we knew Jakarta by its oldest name, Kalapa. Kalapa was documented as one of the important port cities ruled by the Sunda Kingdom $\left(10^{\text {th }}\right.$ century CE) until it was besieged by the alliance of Islamic kingdoms from the east led by Fatahillah in 15261527. Fatahillah then changed Kalapa to Jayakarta. The name "Sunda Kalapa" is still preserved in local memory through the name of Jakarta's old port "Sunda Kalapa". Jayakarta was then occupied by the VOC-Dutch, led by J. P. Coen in 1618. In 1619, Coen developed a city plan and changed the name to Batavia. This name lasted until 1942, when the Japanese occupation renamed Batavia into Jakarta, a version of 
Jayakarta. Batavia grew through wars waged by Banten from the west and Mataram from the east and the area outside the wall became suburbs. These suburbs were occupied by native inhabitants as the non-natives considered safety only available inside the wall. After a new peace treaty with Banten was signed in 1684, more people went out of the wall and developed the areas outside the city wall.

The Batavia city plan became the foundation of Jakarta's development that started in the north then moved towards the south, to higher ground. The move was motivated by increasing security in the Ommelanden (the surrounding area), the unhealthy environment and also ecological deterioration in Batavia. Large scale cultivation, country houses, sugar cane and coffee plantations grew bigger. Continuing the extension, more complicated issues followed. The areal growth required for rice cultivation that necessitated a constant supply of water that interrupted the natural flow of the rivers. This pushed the river into become shallow further while deforestation also caused sudden rise of water levels during the rainy season. Illegal dams grew uncontrolled and unsupervised, while the stench from the canals in the city were reported as the seasonal flooding carried down all kinds of natural and human waste from the upland hinterland (Kanumoyoso 2011: 23-41). Besides the decreasing quality of the water system, malaria caused high mortality rates. Saltwater fishponds laid out surrounding the walled city by Javanese fishermen in 1729 were not used until 1733 which led to mosquitoes breeding and becoming vectors of malaria. In 1729 a malaria epidemic ravaged Batavia and killed thousands of native people and European immigrants (Kanumoyoso 2011: 42, note 115).

Eventually, the city wall was dismantled in 1810 after the VOC went bankrupt in 1799. The Netherlands government took over and made Batavia the capital of the East Indies. Through the $18^{\text {th }}$ and $19^{\text {th }}$ century Batavia became a colonial city that reached its peak in the development of a transportation system; it was cultural exploration and colonial exploitation at its best.

Colonial exploitation in port cities as such in Batavia not only brought commodities from different places, but also people with or without their consent. These centuries of historical migrations formed a multicultural segregated society in Batavia. The highest social group in Batavia was the Europeans, the second was Chinese and Arabs, while the Asian non-Chinese non Arabs people formed the third and lowest social group. Although all came to the city with economic interests, groups of Chinese and Arab descent group kept their interest in trade and did not extend to politics, unless the VOC government required them to. Each of these ethnic groups was headed by captains who were appointed by the VOC, who also had the responsibility to settle conflicts inside their own community.

The city itself was never really intended to be a settlement for the Dutch; it was founded for trade and there was no migration from the Dutch beyond the trading offices. The situation gave the need to "import" more people to work in houses, plantations, offices, factories, sugar mills and even the military. Some people arrived in Batavia for a chance of work such as the Chinese migrants during the peak of sugar industry; some others were brought as slaves. Each community lived in villages (kampongs) that got their names according to the dominant or the origin of the groups that started the residential area. These kampongs can still be found as district names in 
Jakarta, such as Kampung Melayu (kampong of the Malays), Kampung Bali (kampong of the Balinese), Kampung Bandan (kampong of the people from Banda).

The number of occupants grew through time but segregation remained the on-going system for almost four centuries. The system created division and sometimes suspicion between groups. This situation was sometimes utilized by political forces to create chaos and disintegration between the people in Jakarta, even in recent history. For example, the Chinese community was targeted a few times in the city. In 1740 after a crisis in the sugar industry that increased the number of unemployed, tensions rose and the Chinese who were detained in the City Hall and the ones living surrounding the wall (the current area of Glodok Chinatown) were targeted. In May 1998, after the economic crisis and the fall of Soeharto's 32 years of dictatorship, the national political situation was uneasy and the chaos targeted areas with Chinese residents. The chaos also occurred in smaller scale in a few other main cities. At the same year, the use of "pribumi" an Indonesian word that was translated directly from Dutch's racist toned word "inlander" was forbidden by the law. This word was painted on stores and buildings' wall to save them from the Chinese targeting mass in the chaos (Fig. 20).

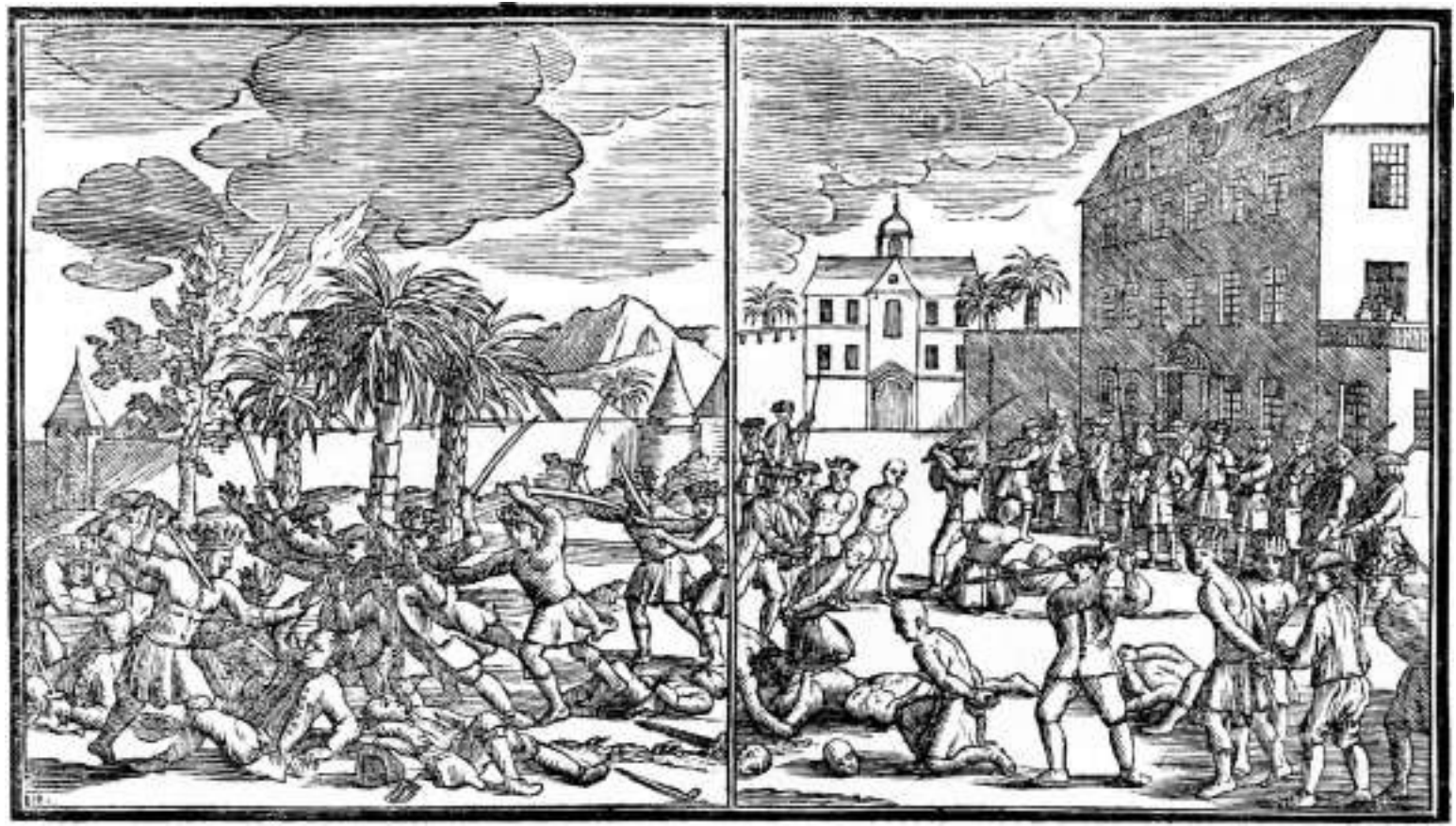

Fig. 20 Chinese Massacre in 1740 inside Casteel Batavia, in the background showed the Stadhuis that is currently the Jakarta History Museum. Source: Van Stolk and Van Rijk (1895).

\section{Kota Tua}

Kota Tua or the Old City area now refers to the area that was once the walled city of Casteel Batavia. Conservation efforts started in 1968 but really kicked off in 1974 when Ali Sadikin, the city governor of that time revitalized the city square area and reused three historical buildings in the square to be what is now known as Museum Sejarah Jakarta (the Jakarta History Museum, also known as Museum Fatahillah), Museum Wayang (Shadow Puppets) and Museum Seni Rupa dan Keramik (Fine Arts 
and Ceramics). Most of the buildings here are categorized as Type A Heritage Buildings, which are the highest and most protected of the class. Fatahillah square, the current name of the city square in front of the Jakarta History Museum (Stadhuis) is a very popular tourist destination where people can gather and hang around with friends and family.

The provincial government of Jakarta is the only province that has the most complete tools for heritage preservation efforts. The city has its own Heritage Review Board; a team of Heritage Preservation Experts who assess the values of heritage and groups them in levels of importance and the Kota Tua area also has its own unit to manage the area and provide daily onsite supervision (Fig. 21). Reinforcement of the heritage law is still lacking here and there: there are some issues such as misinformed private or commercial owners, and also the various government unit that have different responsibilities in the area. Coordination between the units are sometimes lacking and in a few occasions it has cost us irreplaceable heritage.

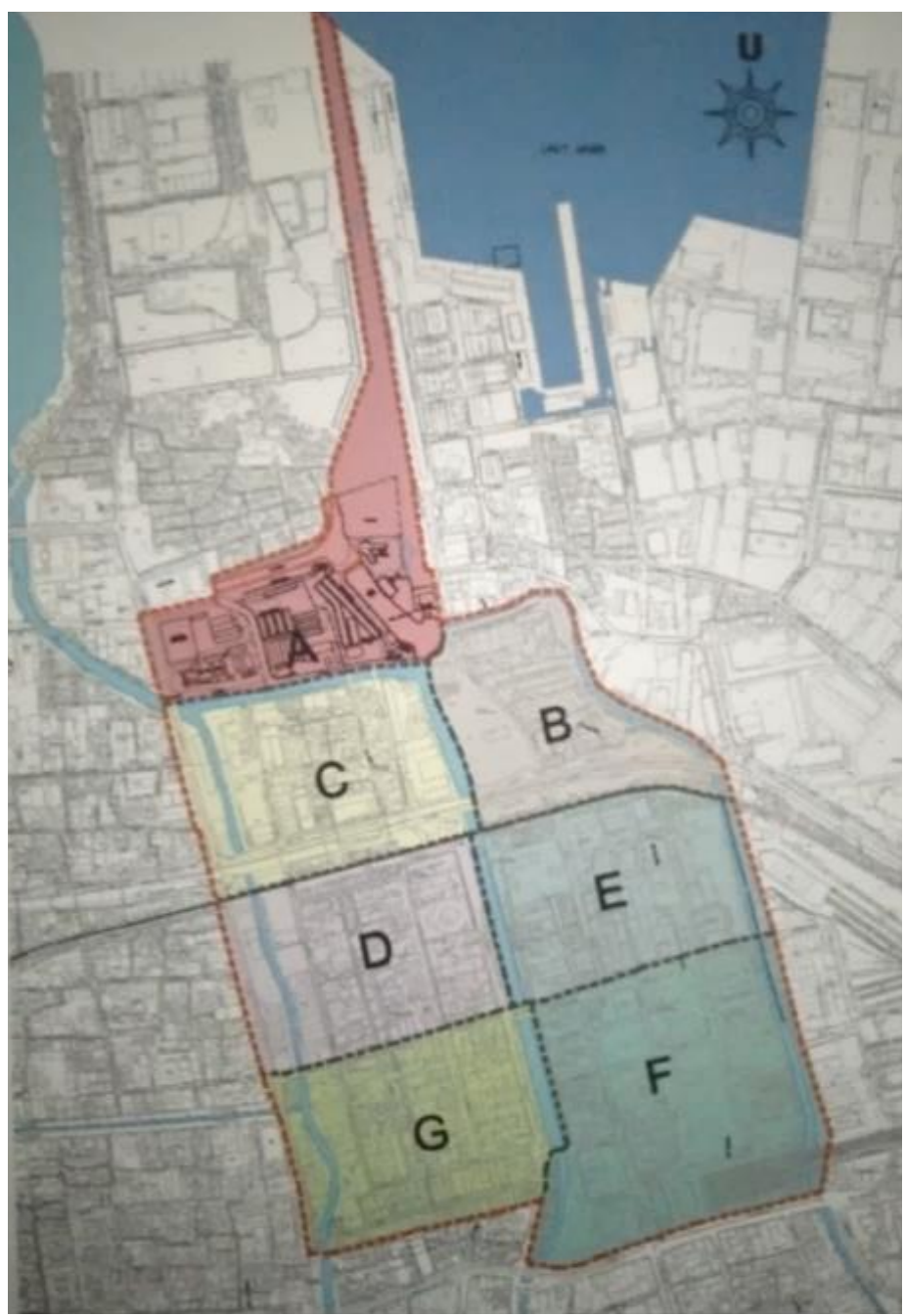

Fig. 21 The division of heritage areas in Kota Tua area: A: Fish market sub area; B: Eastern Warehouse sub area C : Shipyards; D: Jayakarta area; E: North Kali Besar; F: Fatahillah Square; G: South Kali Besar. Source: Heritage Conservation Centre, Office of Tourism \& Culture, Jakarta Province 2016. 
The latest conflict between heritage preservation units and city development happened in Area A, the fish market sub-area, which also where the oldest parts of Kalapa was situated. The removal of illegal squatters in the area was done by the city's Watering System Management unit and was not coordinated with other units such as the conservation office. The removal used hard equipment and that destroyed the remaining heritage (Fig. 22).

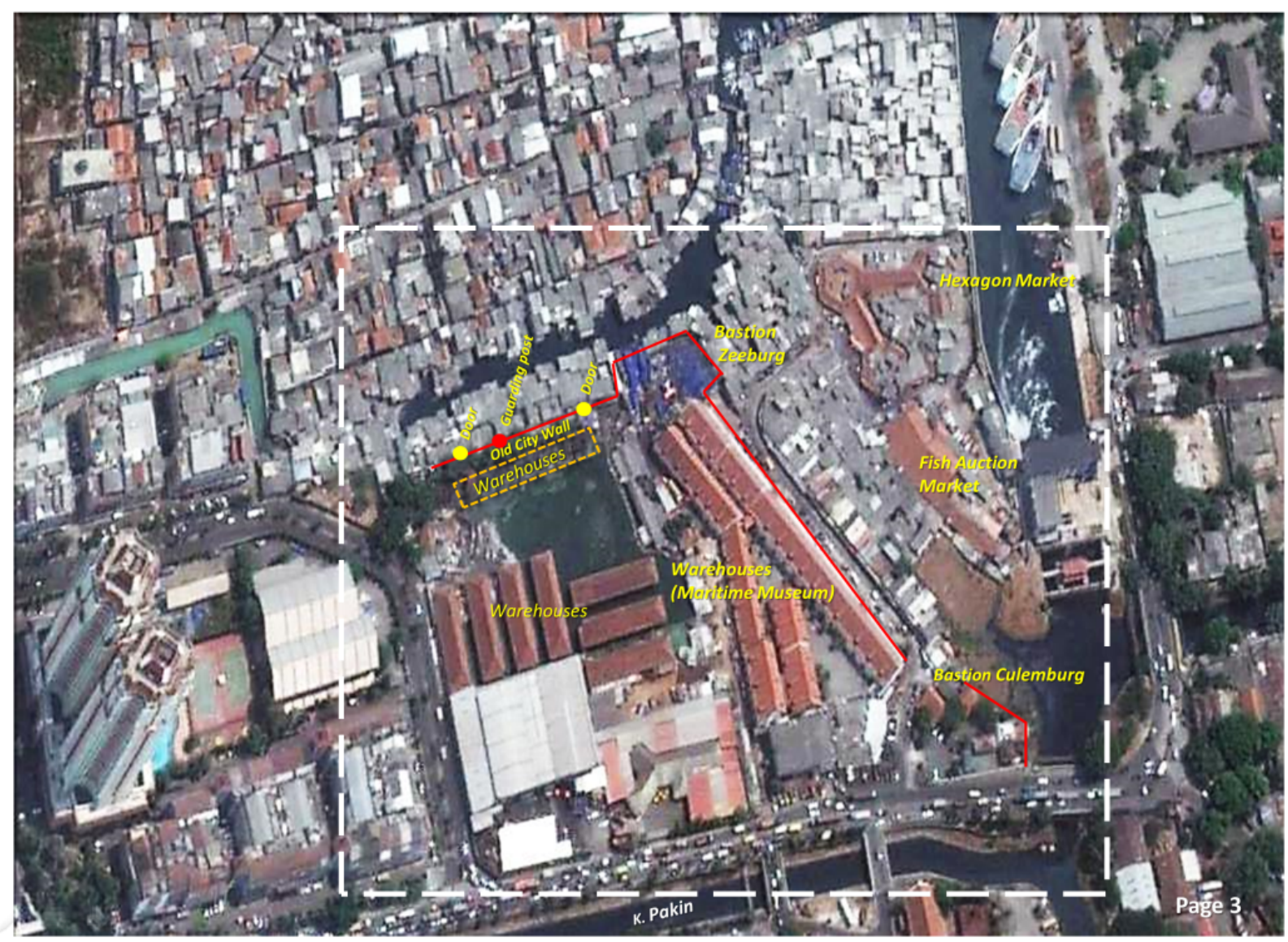

Fig. 22 The exact location of the conflict, on the north city wall. Yellow fonts label the heritage buildings and structures, while the grey areas are illegal squatters before they were removed by force. Source: Mundardjito 2017. 


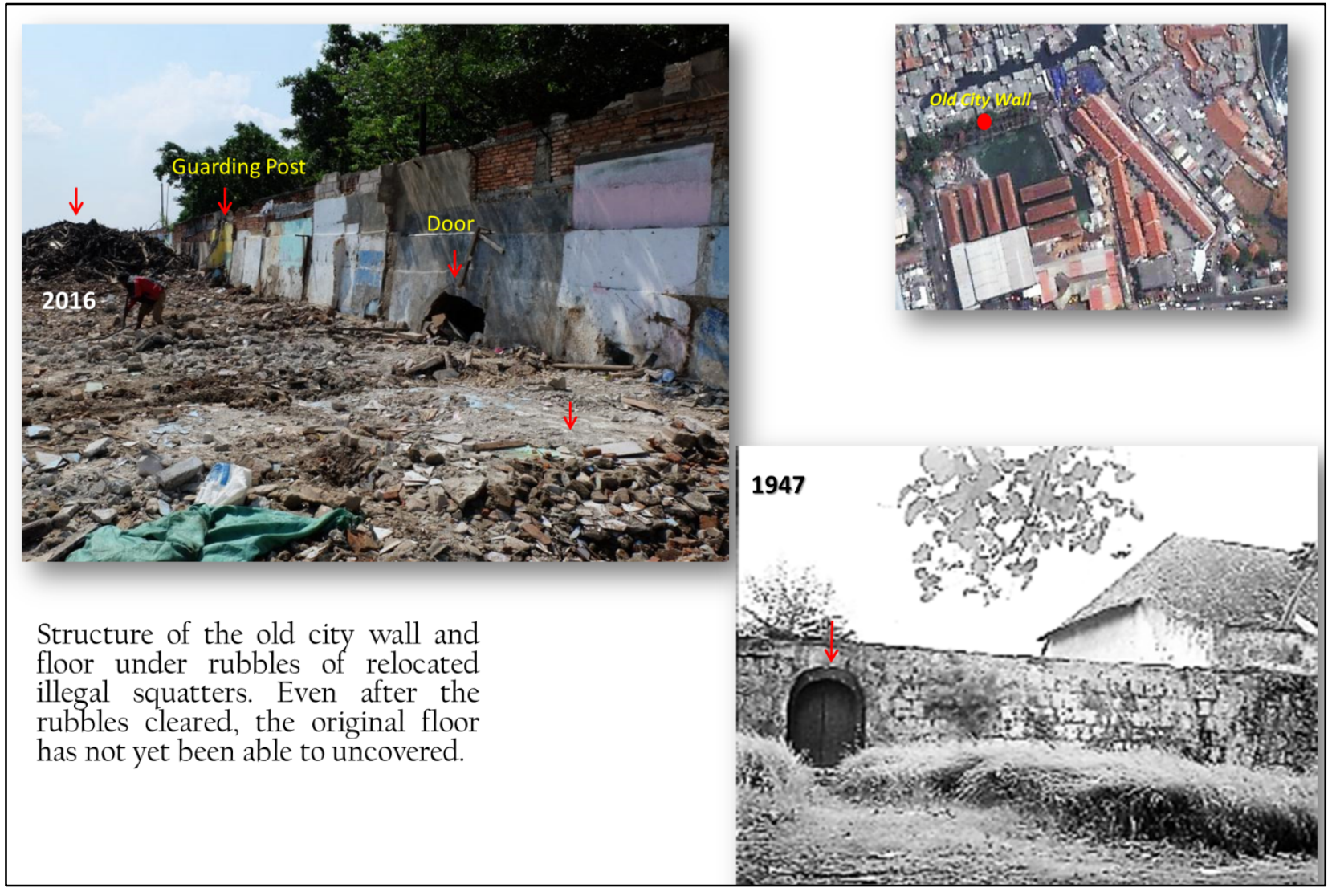

Fig. 23 Aftermath on site as documented and explained by the heritage conservation team. Source: Mundardjito 2017.

The conflict attracted great national attention not only because the removal was quite dramatic on television, but also because the oldest part of the city was being disturbed in the process. A team of archaeologists surveyed the area the next day, made documents and coordinated directly with the governor, Basuki Tjahja Purnama so the issue of heritage preservation can be considered in the government's future plan towards this area. One of the concerns was that the great sea wall of Jakarta was in danger of destruction. Fortunately the governor at this time also has the same spirit as Ali Sadikin has when he revitalized the old city square area in 1974. Basuki, following Joko Widodo' ${ }^{4}$ move, fully supported the revitalization of the old city in the greater length. This case got his full attention and the discussion with the heritage conservation team gave great input on the great Jakarta City wall infrastructure to be in safe distance and to not block the view to the remaining structure. The area now is preparing to be an "integrated" maritime tourism area.

\section{References}

Blusse JL (1986) Strange Company: Chinese settlers, mestizo women and the Dutch in VOC Batavia. Dordrecht: Foris Publication. Google Scholar search

\footnotetext{
${ }^{4}$ Joko Widodo, or Jokowi, was the governor before Basuki Tjahja Purnama, but then elected to be president before his time as governor completed. Basuki replaced Jokowi.
} 
Breuning, HA (1954) Het voormalige Batavia. Een hollandse stede-stichting in de tropen Anno 1619. Amsterdam: Allert de Lange. Google Scholar search

Coedès, G (1968) The Indianized States of Southeast Asia. SB Cowing (trans.). Honolulu: University of Hawaii Press. Google Scholar search

Daud, TA (2003) Warisan Budaya Untuk Semua: Arah Kebijakan Pengelola Warisan Budaya Indonesia di Masa Mendatang [Cultural Heritage for All: Direction of Indonesian Cultural Heritage Manager Policy in the Future]. Yogyakarta: Departemen Arkeologi, Universitas Gajah Mada. Google Scholar search

Djafar, H (1985) Gerabah Prasejarah dari Situs-situs Arkeologi di Daerah Aliran Sungai Ciliwung Wilayah DKI Jakarta. [Prehistoric Pottery from Archaeological Sites along Ciliwung River Flow Area in Jakarta Special region territory] In: Pertemuan Ilmiah Arkeologi III, Ciloto, 23-28 Mei 1983 [Archaeological Scientific Meeting III, Ciloto, 23-28 May 1983]. Jakarta: Pusat Penelitian Arkeologi Nasional, 42-67. Google Scholar search

Djafar, H (1988) Pemukiman-pemukiman Prasejarah di Daerah Jakarta dan Sekitarnya [Prehistorical habitation site in Jakarta and Surrounding Areas]. In: Diskusi Ilmiah Arkeologi VI. Jakarta, 11-12 Februari 1988 [Archaeological Scientific Discussion VI. Jakarta, 11-12 February 1988]. Jakarta: Ikatan Ahli Arkeologi Indonesia, 1-20. Google Scholar search

Djafar, H (2006) Prasejarah Daerah Jakarta dan Sekitarnya. Panduan Koleksi Prasejarah Museum di Tengah Kebun. [Prehistory of Jakarta Region and Surrounding. Guidance of Prehistoric Collection of Museum di Tengah Kebun]. Unpublished report. Google Scholar search

Djafar, H (2009) Ciliwung Sejak Zaman Prasejarah [Ciliwung since Prehistoric Era]. In: M Karim (ed.), Ekspedisi Ciliwung: Laporan Jurnalistik Kompas. Mata Air, Air Mata. Jakarta: Penerbit Buku Kompas. pp 73-83. Google Scholar search

Djafar, H (2010) Kompleks Percandian Batujaya: Rekonstruksi Sejarah Kebudayaan Daerah Pantai Utara Jawa Barat [Batujaya Temple Site Complex: Reconstruction of Cultural History of West Java North Coast]. Bandung: Kiblat Buku Utama/École Française d'Extrême-Orient/Pusat Penelitian dan Pengembangan Arkeologi Nasional/KITLV- Jakarta. Google Scholar search

Heuken, A (1999) Sumber-sumber asli sejarah Jakarta, Jilid I: Dokumen-dokumen sejarah Jakarta sampai dengan akhir abad ke-16 [Jakarta Origin Historical Resource, Book 1: Jakarta historical documents until end of $16^{\text {th }}$ century]. Jakarta: Cipta Loka Caraka. Google Scholar search

Heuken, A (2002) The Earliest Portuguese Sources for the History of Jakarta: including all other historical documents from the $5^{\text {th }}$ to the $16^{\text {th }}$ centuries. Jakarta: Cipta Loka Caraka. Google Scholar search

Heuken, A (2007) Historical Sites of Jakarta. Cipta Loka Caraka, Jakarta. Google Scholar search

Heuken, A (2011) Sumber-sumber Asli Sejarah Jakarta. Cipta Loka Caraka, Jakarta. Google Scholar search

Heuken, A (2016) Tempat-tempat bersejarah di Jakarta [Historical Sites of Jakarta], $2^{\text {nd }}$ edition, Jakarta: Cipta Loka Caraka. Google Scholar search

Kanumoyoso, B (2011) Beyond the city wall: society and economic development in the Ommelanden of Batavia, 1684-1740. PhD thesis, Leiden University, Leiden. Google Scholar search 
Milone, PD (1966) Queen City of the East: The Metamorphosis of a Colonial Capital. $\mathrm{PhD}$ Dissertation, University of California, Berkeley. Google Scholar search

Kwanda, T (2011) The Morphological Framework of the Chinese and the European Districts in Surabaya, 1787-2005. DIMENSI (Journal of Architecture and Built Environment) 38(1): 1-14. Crossref

Noorduyn, J and Verstappen, H. Th. (1972) Purnawarman's Riverworks near Tugu. Bijdragen tot de taal-, land- en volkenkunde 128(2): 298-307. Crossref

Poerbatjaraka and Hadidjaja T (1952) Kepustakaan Djawa [Djawa's Literature], Djakarta: Djambatan. Google Scholar search

DKI Jakarta (1977) Almanak DKI Jakarta. Jakarta: DKI Jakarta. Google Scholar search

Pires, T (1990/1512-1515). The Suma Oriental of Tome Pires: An Account of the East, from Red Sea to China. New Delhi: Asian Educational Services, New Delhi. Google Scholar search

Soejono, RP (ed.) (1984) Sejarah Nasional Indonesia: Jilid I. Jaman Prasejarah [Indonesian National History: Book 1 . Jakarta: Balai Pustaka. Google Scholar search

van der Brug, PH (1994) Malaria en malaise-De VOC in Batavia in de achttiende eeuw [Malaria in discomfort-The VOC in Batavia in the eighteenth century]. Amsterdam: De Battafsche Leeuw. Google Scholar search

van der Hoop, ANJ (1941) Catalogus der Prehistorische Verzameling van het Bataviaasch Genootschap van Kunsten en Wetenschappen [Catalog of the Prehistoric Collection of the Batavian Society of Arts and Sciences]. Bandung: A.C. Nix \& Co. Google Scholar search

van Stolk, A and van Rijk, G (1895). Atlas van Stolk. Katalogus der historie-, spot-en zinneprenten betrekkelijk de geschiedenis van Nederland [Stolk's Atlas, Catalog of history relative to the history of the Netherlands]. Amsterdam: F. Muller \& Co. Google Scholar search

Verstappen, H. Th (1953) Djakarta Bay: A Geomorphological Study on Shoreline Development. The Hague: Drukerij Trio. Google Scholar search

Widianto, H (2006) The Cranio-morphological Aspects of the Recent Discovery of Human Remains from Batujaya, West Java. In: T Simanjuntak, M. Hisyam, Bagyo Prasetyo, Titi Surti Nastiti (eds.) Archaeology: Indonesian Perspective. R.P. Soejono's Festschrift. Jakarta: Lembaga Ilmu Pengetahuan Indonesia. 124-135. Google Scholar search 